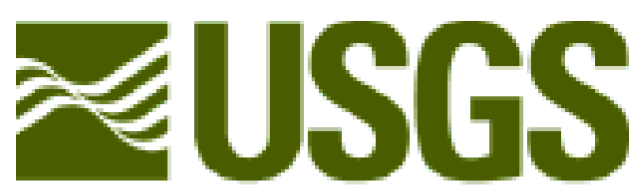

science for a changing world

\title{
USE OF STRUCTURAL GEOLOGY IN EXPLORATION FOR AND MINING OF SEDIMENTARY ROCK- HOSTED AU DEPOSITS
}

\section{By Stephen G. Peters}

Open-File Report 01-151

This report is preliminary and has not been reviewed for conformity with U.S. Geological Survey editorial standards or with the North American Stratigraphic Code. Any use of trade, product, or firm names is for descriptive purposes only and does not imply endorsement by the U.S. Government.

\section{U.S. DEPARTMENT OF THE INTERIOR U.S. GEOLOGICAL SURVEY}

United States Geological Survey, Reno 
Abstract

Structural geology is an important component in regional-, district- and orebody-scale exploration and development of sedimentary rock-hosted Au deposits. Identification of timing of important structural events in an ore district allows analysis and classification of fluid conduits and construction of genetic models for ore formation. The most practical uses of structural geology deal with measurement and definition of various elements that comprise orebodies, which can then be directly applied to ore-reserve estimation, ground control, grade control, safety issues, and mine planning. District- and regional-scale structural studies are directly applicable to long-term strategic planning, economic analysis, and land ownership.

Orebodies in sedimentary rock-hosted Au deposits are discrete, hypogene, epigenetic masses usually hosted in a fault zone, breccia mass, or lithologic bed or unit. These attributes allow structural geology to be directly applied to the mining and exploration of sedimentary rockhosted Au deposits. Internal constituents in orebodies reflect unique episodes relating to ore formation. The main internal constituents in orebodies are ore minerals, gangue, and alteration minerals that usually are mixed with one another in complex patterns, the relations among which may be used to interpret the processes of orebody formation and control. Controls of orebody location and shape usually are due to structural dilatant zones caused by changes in attitude, splays, lithologic contacts, and intersections of the host conduit or unit. In addition, conceptual parameters such as district fabric, predictable distances, and stacking also are used to understand the geometry of orebodies. Controls in ore districts and location and geometry of orebodies in ore districts can be predicted to various degrees by using a number of qualitative concepts such as internal and external orebody plunges, district plunge, district stacking, conduit classification, geochemical, geobarometric and geothermal gradients, and tectonic warps. These concepts have practical and empirical application in most mining districts where they are of use in the exploration for ore, but are of such broad and general application that they may not represent known or inferred ore formation processes. Close spatial relation among some sedimentary rockhosted Au deposits and their host structures suggests that the structures and the orebodies are genetically linked because they may have shared the same developmental history. Examples of probable syn-deformational genesis and structural control of sedimentary rock-hosted $\mathrm{Au}$ deposits are in the large Betze deposit in the Carlin trend, Nevada and in the Lannigou, Jinlongshan, and Maanqiao Au deposits, China. 


\section{INTRODUCTION}

Understanding epigenetic or structurally controlled orebodies and predicting their location, shape, and plunge has always been a major concern of economic geologists (Penrose, 1910; Hulin, 1929; Blanchard, 1931; Conolly, 1933; McKinstry, 1941, 1955; Newhouse, 1942). Because each mining district or camp has its unique geologic characteristics and history, terminology and structural techniques applied to exploration and mining of ore deposits have evolved differently in each district. Recent high discovery rates of sedimentary rock-hosted Au deposits in northern Nevada has led to application of traditional and new structural techniques to these deposits. Special properties of sedimentary rock-hosted Au deposits, particularly their propensity to be hosted in incompetent, low-grade or un-metamorphosed sedimentary rocks that have undergone extensive dissolution, make structural geology an important component for their discovery and extraction.

Syn-deformational or orogenic ore deposition has been proposed for some sedimentary rock-hosted Au deposits by Peters and others $(1998,2000)$ in Nevada and by Lou Xiaohuan (1993; 1994; 1996) and by Peters and others (2001a,b) for some Carlin-type Au deposits in China. Formation of some sedimentary rock-hosted Au deposits in Nevada has been shown to be synchronous with regional-scale deformation and many Au ores locally display textures that also contain syn-deformational features.

Field and laboratory evidence for the introduction of Au-bearing fluid during deformation in Nevada and Chinese deposits suggests interaction of fluids with localized deformation events in the upper crust that have been documented elsewhere (McClay, 1977; Henley, 1973; Henley and Ethridge, 1994; Hickman and others, 1994; Logan and Decker, 1994). Deformational events that involve fluids commonly are regarded as extensions of deep crustal fluid-deformation interactions in the ore-forming environment (see also, Fyfe and others, 1978; Ethridge and others, 1983; O'Hara, 1998). These deformation events are distinct from high-level, brittle deformation that is typical of many epithermal deposits. Sedimentary rock-hosted Au deposits with brittle-ductile features in altered carbonate rocks may be related to deeper processes and most likely formed during tectonic events that were accompanied by significant fluid flow. Deformation-fluid interactive processes in the formation environment of sedimentary rock-hosted Au deposits involve faulting, shearing, and gouge development along illite-clay-altered and decalcified zones that were followed by continued hydrothermal alteration, which resulted in increased porosity and enhancement of fluid flux along the host conduits. The processes also may have involved zones of hydrofracture due to high fluid pressures (see also, Byerlee and Brace, 1972; Phillips, 1972, 1986; Engelder, 1974). These environments also typically are associated with local fluctuations in pressure and temperature that affected variation in fluid chemistry during orebody formation.

Structural control of sedimentary rock-hosted Au orebodies involve regional- or districtscale structural fabrics that have resulted from multiple tectonic events ffig. 1). Several orebodies clustered together may form discrete parts of a larger orebody, such as the Betze-Post-Screamer cluster in the Goldstrike Mine. Several conduits may connect in ore districts. An individual ore district typically will represent a single, connected plumbing system with a common fluid source and therefore orebodies within a district commonly show similarities of alteration, mineralization and structural controls, which distinguishes them from other ore districts. Plunges of individual orebodies within an ore district may be related to the geometry of the entire ore district. 


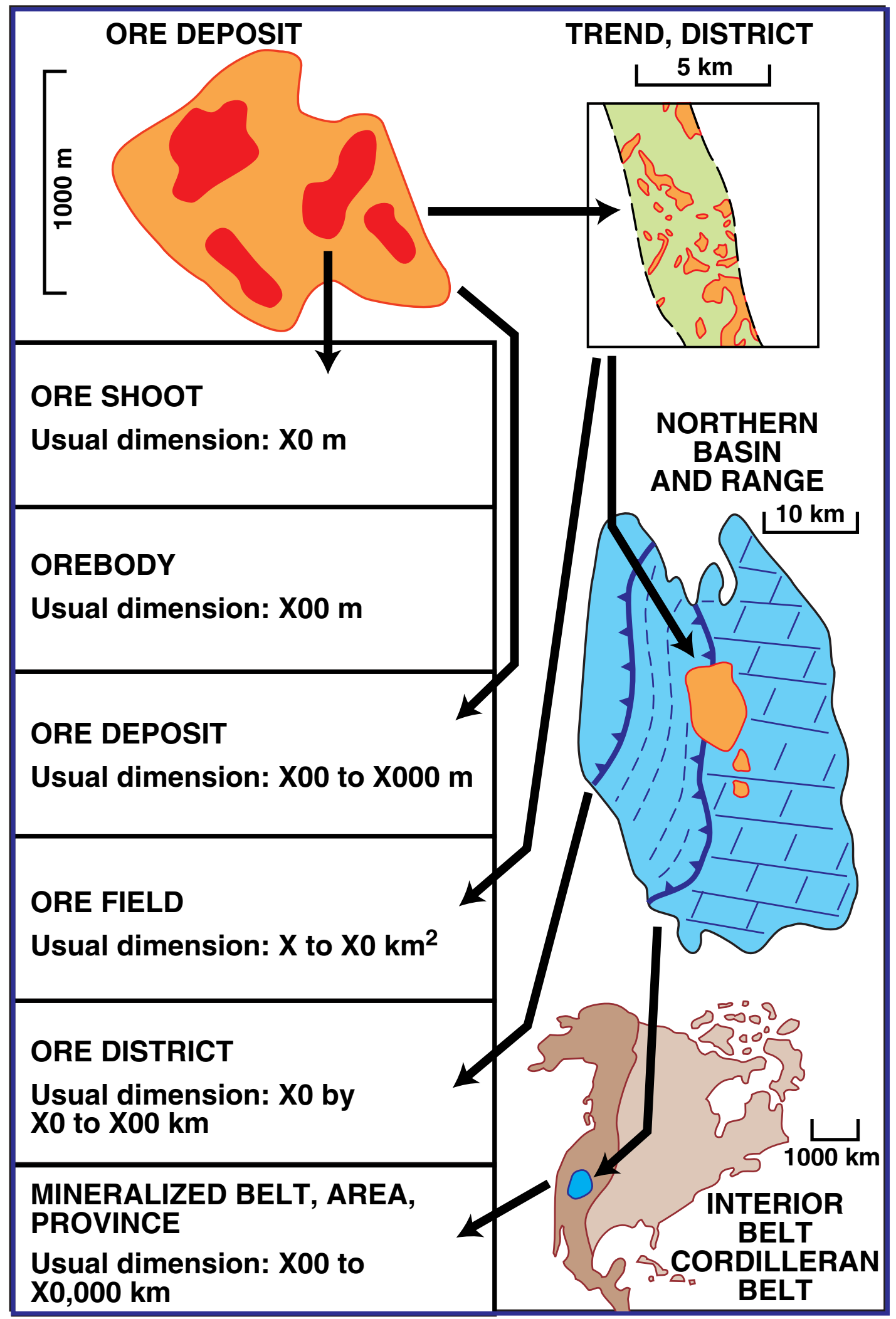

Figure 1. Diagram showing scale ranges of tectonic and structural bodies relevant to the study of sedimentary rock-hosted Au deposits in North America. Regional-scale fabric and grain may be manifested in smaller district- and orebody-scale fabrics and therefore locally may control ore. 
This paper summarizes and discusses some commonly used structural tools and concepts that can be used in sedimentary rock-hosted Au deposits and gives some examples of syndeformational ores in this type of deposit in Nevada and in China.

\section{APPLICATIONS OF STRUCTURAL GEOLOGY}

The role of the geologist in the discovery, planning, and extraction of orebodies is vital (Mclaughlin and Sales, 1933; Clark, 1948; Henderson, 1965; Peters, 1966; Pillar and Drummond, 1975; Reedman, 1979) because orebodies are geologic entities that possess discrete mineral assemblages, geochemical signatures, rock-strength characteristics, and form. Structural geology, as practiced in the exploration and mining of orebodies, specifically deals with the form and geology of ore that is derived from the host lithologies and structures. Techniques of structural geology are the only means by which orebodies can be measured, whether these techniques are used by geologists or by engineers (Popoff, 1966; Kužvart and Böhmer, 1978; Storrar, 1981). Techniques of ore-reserve estimation (Hazen and Gladfelter, 1964; Hewlett, 1970; King and others, 1982; Kwa and Jones, 1986), grade control, mine lay out, and many other routine parts of a mining operation also are dependent on traditional applications of structural geology (figs. 2 and 3).

Structural parameters of sedimentary rock-hosted $\mathrm{Au}$ orebodies are discrete hypogene masses hosted in structural or lithologic units, which also may have acted as conduits for the ore fluids. These units commonly are referred to as a channel, surface, or lode and may be a shear zone, fissure, fault zone, or a specific lithologic interval or lithologic boundary. Geometry of orebodies is expressed with reference to breadth, and strike lengths $(>3,000 \mathrm{~m})$ and by dip (Lindgren, 1933; Jensen and Bateman, 1981), and plunge lengths (100 to >500 m). Orebodies are characterized by higher metal content than adjacent parts of the host conduit. Mass of most orebodies ranges between $2 \times 10^{4}$ and $1 \times 10^{8}$ tonnes. Parts of orebodies and conduit systems may be named as if they were parts of fault systems (see also, Ramsay and Huber, 1983, 1987).

A common tendency is for orebodies to be thicker and richer in the center or in a lobe or along one side, rather than to be uniform in overall grade distribution. Orebodies may terminate abruptly or may taper in thickness or grade to assay cut-offs. Usually, terminations are geologic features, such as faults, as well as lithologic or alteration boundaries. Thickness of sedimentary rock-hosted $\mathrm{Au}$ orebodies typically is between 10 to $300 \mathrm{~m}$. Subsidiary mineralized zones may connect to a main orebody and orebody configurations may take the form of mantos, veins, pipes, or even stockworks (Peters and others, 1998). Plunge of an orebody is defined as the trend and inclination from the horizontal of its central (best fit) axis. Rake or pitch of an orebody refers to the angle between its central axis and the horizontal within a planar surface, such as the host conduit or a projection plane (Lindgren, 1933).

\section{INTERNAL CONSTITUENTS}

A characteristic feature of structurally-controlled orebodies is their complexity. Internal mineralogical constituents in these complex orebodies usually reflect unique episodes relating to ore formation. Orebodies are composed of specific ore mineral assemblages that are distinct from mineral assemblages and rock types outside the orebody. Between orebodies, gangue, alteration mineral assemblages, and gouge define barren or lower-grade parts of the host unit or conduit. These constituents usually are mixed with one another in complex patterns, the relations among which may be used to interpret processes of orebody formation and paragenesis (Ramdohr, 1969; Stanton, 1972). Recognition of zoning, growth types, intergrowths, contact rims, impurities, and repetitions allow inferences on the geologic history of the orebody. 


\section{Method:}

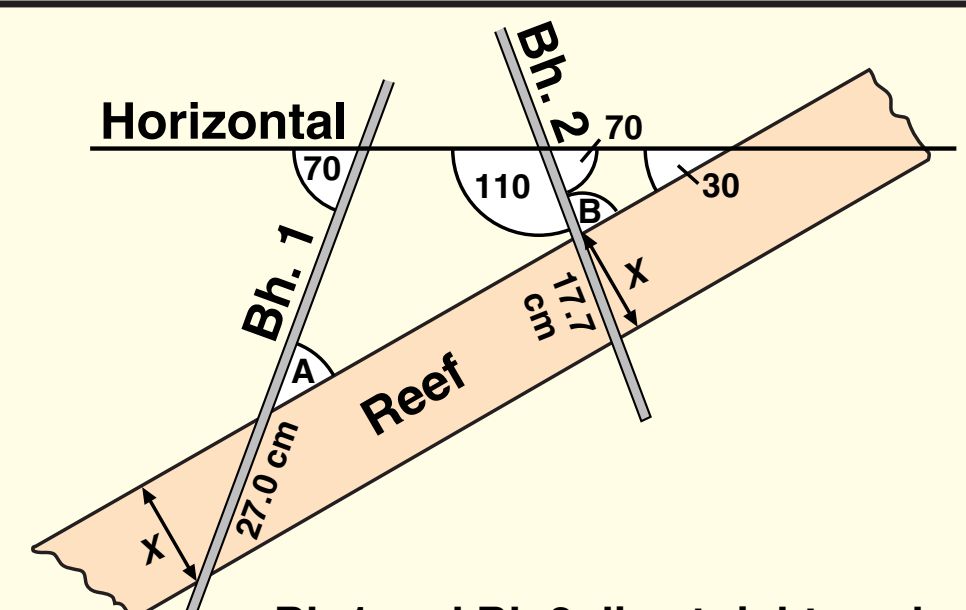

Bh 1 and Bh 2 dip at right angles to strike reef

$$
\begin{aligned}
& \text { width } x=Y \sin B \\
& =27.0 \sin 40=17.4 \mathrm{~cm}
\end{aligned}
$$

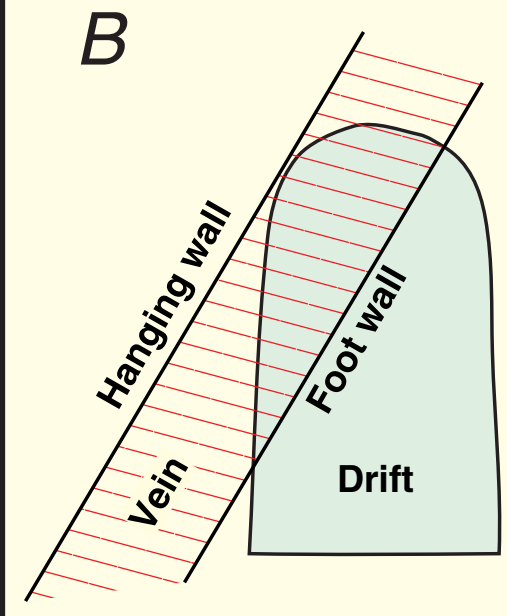

a. Best position

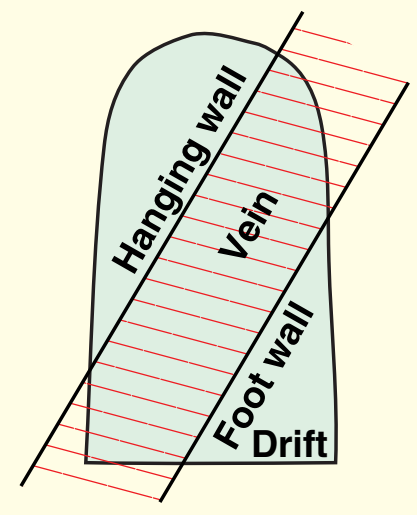

b. Poor position

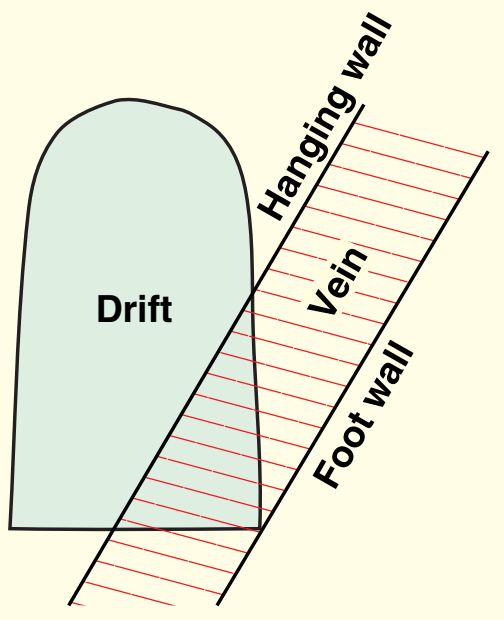

c. Poor position

\section{SKETCH SHOWING DRIFT IN RELATION TO POSITION OF VEIN}

Figure 2. Simplified examples of use of structural features for measurement of ore and mine design. (A) Identification and measurement of true dip of ore in drilling, sampling or underground development is vital to accurately measure ore volumes and location. $(B)$ Use of attitude in layout of underground workings relative to position of the orebody (modified from Storrar, 1981). 


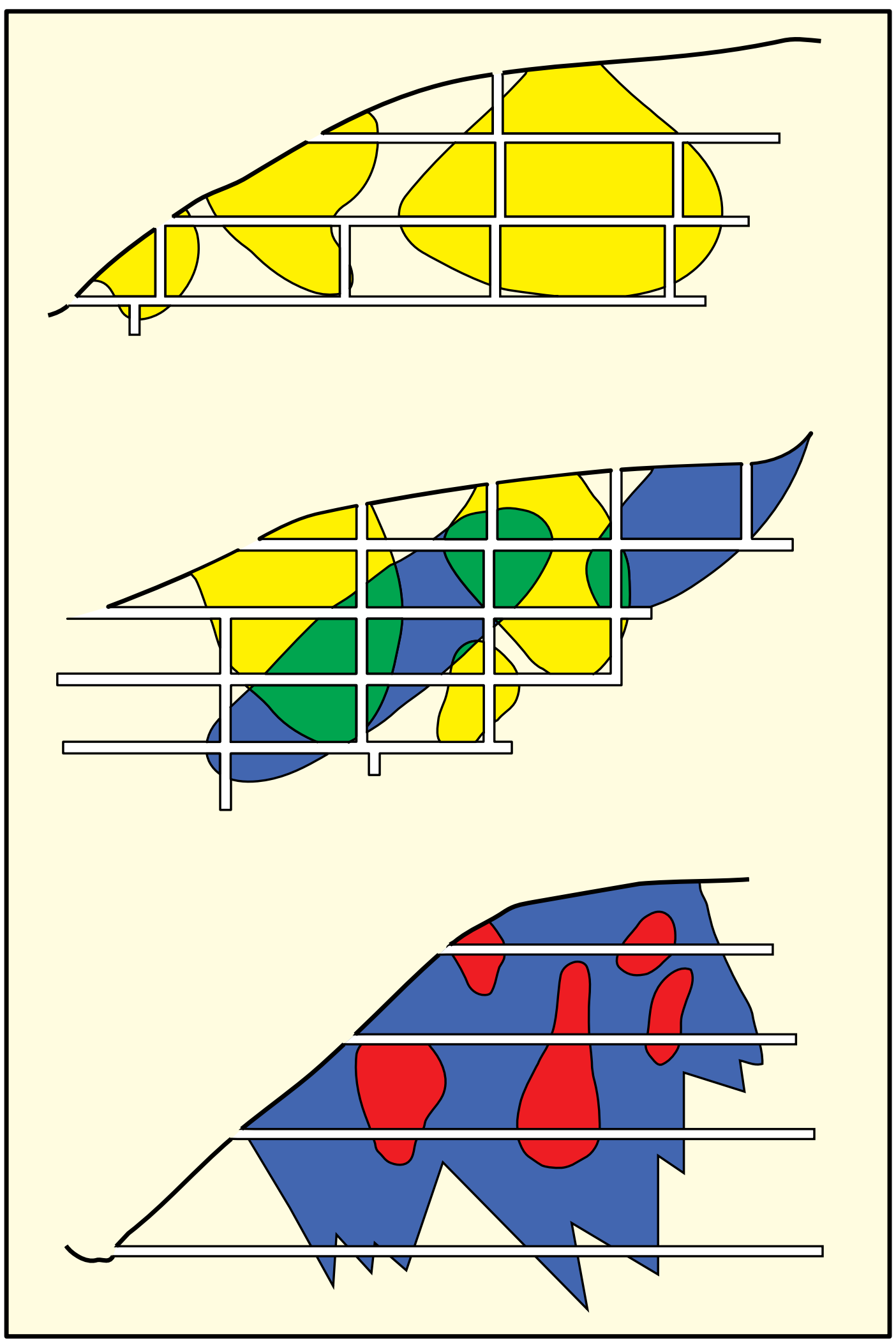

Figure 3. Hypothetical longitudinal projections of relations among mine layout and shape and size of the orebody. Use of structural geology dictates the array of workings by defining the shape and probable location of the orebody and oreshoots and by outlining ground control problems (adapted from Kuzvart and Böhmer, 1978). 
Textural relations among internal constituents allow discrimination of the processes of orebody formation. Textures found in orebodies may represent pre-, syn- and post-ore events in the host conduit. Multiple fluid episodes, different fault movements, and chemical replacements all may have specific textural signatures. Ore fluid usually is drawn to these areas of multiple structural episodes where high complexity and porosity may predate the main mineralizing event. Textural variation is common within, between, and along orebodies and conduits. For example, ore and gangue minerals may cement brecciated wall rock material, or brecciated ore and gangue minerals may be cemented by subsequent stages of mineralization. Internal constituents form different types of textural and mineralogical components in the mineralized rock of the orebody, in the petrology of the fluid conduits, and in the hydrothermal alteration zones associated with the orebody.

\section{Mineralized rock}

Mineralized hypogene sedimentary rock-hosted $\mathrm{Au}$ ores contain $\mathrm{Au}$ in disseminated sulfide ore minerals and some native $\mathrm{Au}$ - the most prized variants of these orebodies are those that are oxidized completely. Unoxidized ore minerals usually are associated with gangue minerals such as quartz, or carbonate minerals, all of which may be present in veins or veinlets, as disseminations, in wall rock inclusions, or within the wall rock itself in the alteration zone surrounding the main conduit. Deposition of ore minerals may be simultaneous, successive or overlapping. Gold-stage ore deposition begins with disseminated pyrite, followed by As-rich pyrite with micron-scale Au deposited as a separate phase or contained in As-rich rims developed on early pyrites, similar to those described by Wells and Mullen (1973), Bakken and others (1989), Arehart and others (1993), and Fleet and Hamid (1997). Temporal relations among mineral phases is indicated by most workers to start with the deposition of this pyrite with $\mathrm{Au}-$ rich, As-rich rims, followed by ore rich in orpiment-realgar, barite, stibnite, and mercury and base metal minerals. This paragenetic sequence also is the same as that simulated by geochemical modeling of typical Carlin-type systems due to fluid-rock interaction and to cooling of the hydrothermal system from $210^{\circ}-200{ }^{\circ} \mathrm{C}$ to $180-150{ }^{\circ} \mathrm{C}$, at moderate salinity $(<10 \mathrm{wt}$. percent $\mathrm{NaCl}$ equivalent) (Hofstra and others, 1991; Woitsekhowskaya and Peters, 1998). Texture of gangue minerals also helps elucidate the geologic history of the orebody. Quartz, illite-clay, and carbonate minerals are the most common gangue minerals in most sedimentary rock-hosted $\mathrm{Au}$ orebodies. Several stages of quartz with a number of different textures are present in sedimentary rock-hosted Au deposits (see also, Leonardson and Rahn, 1996).

\section{Conduit Petrology}

Ore conduits are present at regional- district- and orebody-scales and are filled with mixtures of crushed and brecciated wall rock, gouge, phyllonite, clay seams, foliated rock, gangue, and altered wall rocks (see also, Peters, 1993a). These constituents are important indicators of how the orebody may have formed, particularly if the fault may have been reactivated. Fault-rock petrology can be related directly to wall rock type, as discussed by Sibson (1977) and Snoke and others (1998). For instance, quartz gouge (Engelder, 1974) is most common in granitoid or sandstone host rocks; whereas, pelitic rocks more commonly generate montmorillonite, illite, and muscovite-rich phyllonite and clay seams (fluchan). The type, amount, or thickness of gouge proximal to or within a segment of the host conduit may be proportional to the relative amounts of movement in that area of the fault plane (Robertson, 1983; Hull, 1988; Walsh and Watterson, 1988; 1989), and also may indicate specific areas along the conduit of greater shear or compressional strain as distinct from zones of dilation. 
Many sedimentary rock-hosted Au deposits and their associated conduits contain or are composed of breccia of different types. The most significant breccia types are sedimentary, collapse and decalcification breccia, tectonic or structural breccia, hydrothermal breccia or breccias with multiple episodes or genesis referred to as polygenetic breccias (Peters and others, 1997). Recognition of breccia types is an important factor in mining of and exploration for these deposits because ore may be contained in only one or a number of these breccia types. For instance, decalcification, argillization, silicification, and deformation commonly overprint early decalcified and collapse breccia, which may have been superimposed over sedimentary breccia (fig. 4).

\section{Hydrothermal alteration}

Patterns of alteration zoning on an orebody scale define dilated zones that have attracted and concentrated fluid flow (Rose and Burt, 1979). Typically, a central elliptical core zone is present in the wall rock as productive alteration adjacent to orebodies, and fringe zone alteration is present outside, along dip, or strike of the orebodies within the same conduit (fig. 5). Fringe zone alteration is chemically or thermally related to productive alteration and commonly contains lowgrade mineralized rock. Barren alteration also may be present along the same conduit, and although it is part of the same mineralizing event, barren alteration indicates places where thermal and chemical conditions were not ideal for the formation of mineralized rock. Unrelated alteration is alteration that came before or after the mineralizing event-early- or mid-barren alteration of Lovering (1949) — and commonly lies outside the host conduit (fig. 5).

Alteration types associated with $\mathrm{Au}$-mineralized rocks in sedimentary rock-hosted $\mathrm{Au}$ orebodies include: carbonation (carbon introduction), decarbonatization ( $\cong$ decalcification), argillization (illite-clay), and silicification. These productive alteration types are similar to alteration types described by Radtke (1985), Bakken and Einaudi (1986), Kuehn and Rose (1992), and Arehart (1996). Pre-Au, unrelated alteration assemblages include syngenetic or diagenetic minerals in host sedimentary rocks, as well as pre-ore contact metamorphic and metasomatic minerals. Restriction of alteration assemblages to narrow selvages implies that fluid flow was restricted to high permeability zones within a host conduit. Broad alteration envelopes around orebodies suggest that the orebodies were the sites of maximum fluid flow in the fissure plane, and also were sites of the greatest porosity and greatest lateral dispersion into the wall rock. In addition, more "reactive" wall rocks lead to wider alteration haloes than lesser reactive rocks along the same conduit. Wide alteration zones, some as wide as $1,500 \mathrm{~m}$, and intense and widespread decarbonatization in sedimentary rock-hosted Au deposits suggests that extremely high fluid flow took place in these systems to account for the large volumes of fluid-rock interaction.

Local areas of carbon inside the orebodies may have been important in the deformation history, because they represent areas of low shear strength and were therefore commonly areas of high strain. Clay minerals in these rocks synchronously precipitated during deformation. Silicified breccia bodies and cataclastic zones commonly are isolated structurally, surrounded by phyllonitic illite-clay seams or by fault gouge, also indicating post-silicification shear zone movement. 

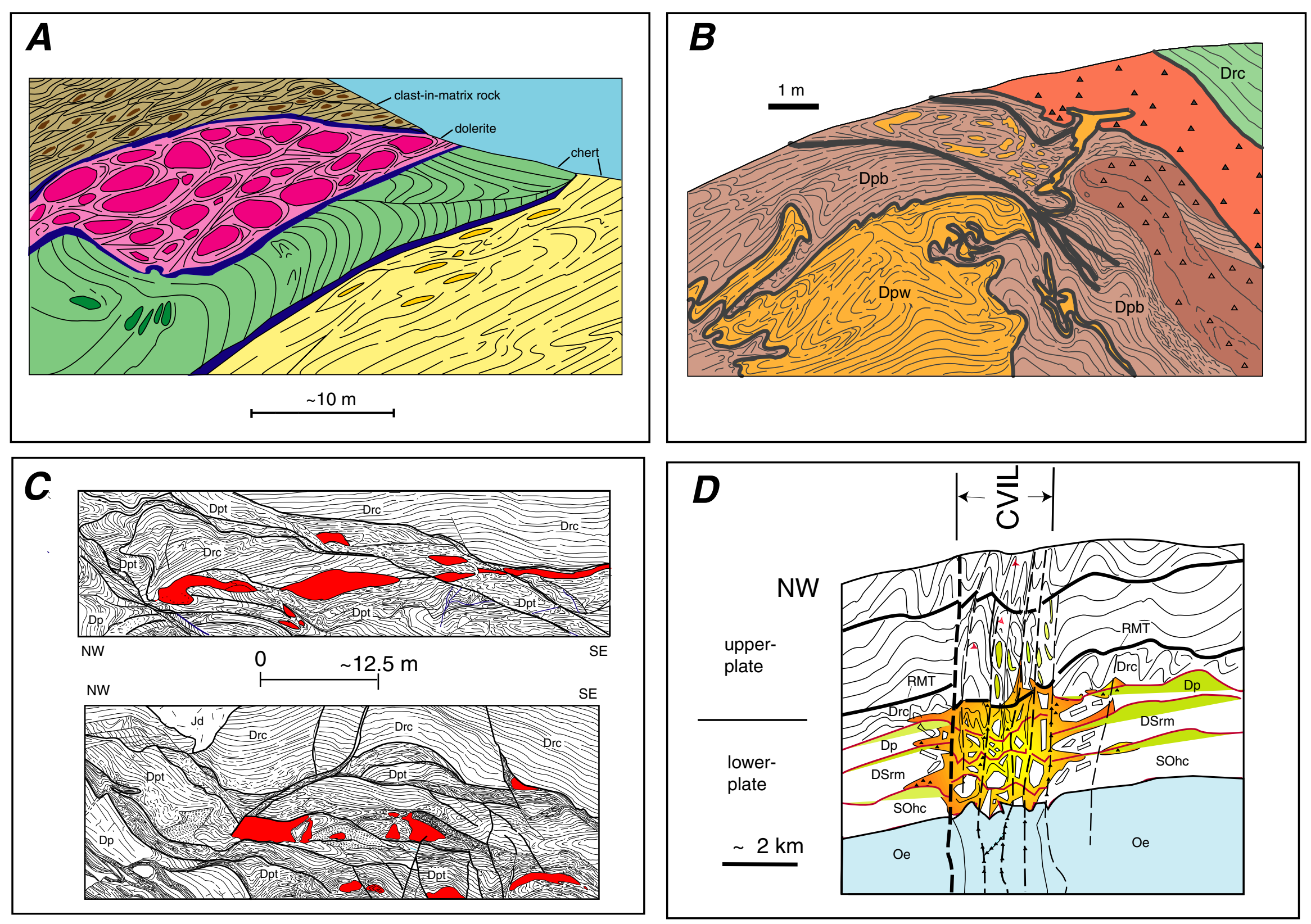

Figure 4. Examples of ore deposit- and conduit-scale deformation textures in sedimentary rock-hosted Au deposit areas resulting from dissolution. (A) Mélange textures in upper plate rocks, Carlin Mine area. (B) Contact between Popovich limestone and Rodeo Creek unit, Betze Mine. (C) Contact between Popovich Formation and Rodeo Creek unit, Betze orebody, Goldstrike Mine. (D) Idealized cross section through the Crescent Valley-Independence lineament (CVIL) at about $42^{\circ}$ latitude. For details, see Peters and others (1998) and Peters (1997, 2000). 


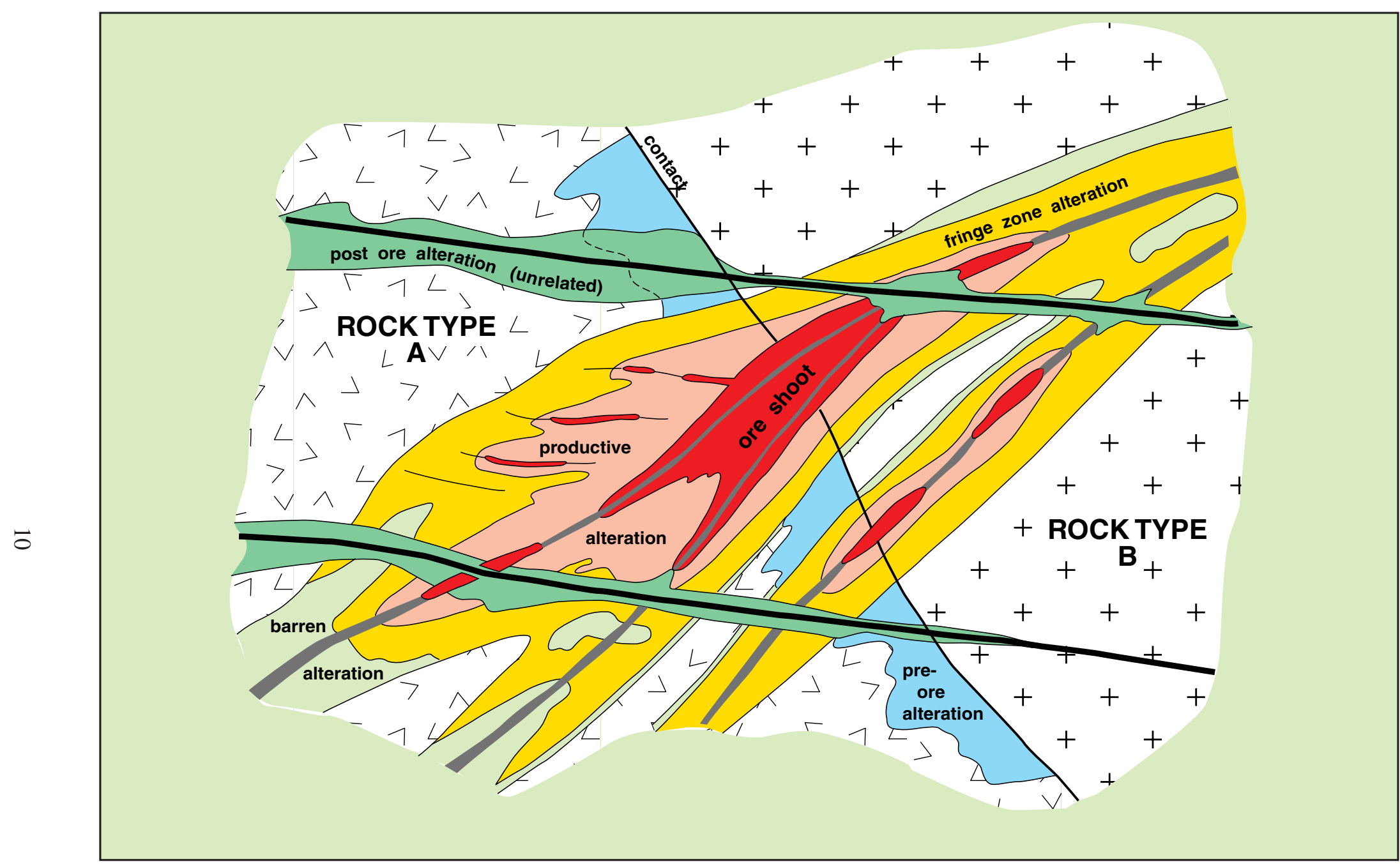

Figure 5. Sketch of a plane or section of an hypothetical oreshoot at a contact between two rock types (+'s and v's). Barren pre-ore alteration may have contributed to early ground preparation. Productive alteration surrounds and is in direct contact with the oreshoot, which contains gangue and mineralization. Fringe zone alteration occurs outside the productive alteration. Barren alteration may also be related to the same fluid or mineralizing event, but may signify different chemical ore physical conditions. Post-ore alteration usually is unrelated but may locally overprint mineralization. 
Hydrothermal alteration may directly affect development of orebodies, by causing mechanical and chemical changes to wall rocks in areas of high fluid flow. These changes produced localized ground softening or hardening (ground preparation). Ground softening (argillization or pervasive clay alteration) results in weaker zones that control the localization of subsequent faulting and shearing. Ground hardening leads to development of competency of the host rocks and favors fracturing, brecciation, and increased porosity. Chemical ground preparation also results from hydrothermal alteration (see also, Coveney, 1981; Woitsekhowskaya and Peters, 1998) and alteration processes also may add heat to the system if it involves exothermic reactions (Cathles, 1977).

Alteration plays a physical as well as chemical role in ground preparation, fault enhancement, silica introduction, and heat generation in orebody development. Alteration may have a direct effect on rock strength. Local areas of carbon inside the orebodies may have been important in the deformation history, because they represent areas of low shear strength and were therefore commonly areas of high strain. Clay minerals in these rocks synchronously precipitated during deformation. Silicified breccia bodies and cataclastic zones commonly are isolated structurally, surrounded by phyllonitic illite-clay seams or by fault gouge, also indicating postsilicification shear zone movement. Zones of illite-clay alteration in shear zones and faults enhance movement due to lesser tensile strength of these alteration minerals than in adjacent unaltered wall rock. Argillization also may influence the evolution of the fluid by hydrated clay minerals releasing or absorbing saline fluids, and planar illite-clay phyllonitic zones may form local pressure seals that affect channeling of fluids (Wang and Mao, 1979; Wang and others, 1979; Moore and others, 1989).

\section{STRUCTURAL CONTROL OF OREBODY LOCATION AND SHAPE}

Orebodies are most common in dilatant zones caused by changes in attitude, splays, lithologic contacts, and intersections (see also, Hulin, 1929; Behre, 1937; McKinstry, 1955; Bursnall, 1989; Hodgson, 1989). In addition, conceptual parameters such as district fabric, predictable distances, and stacking, which are defined below, are useful components to locate and measure orebodies. Favorable sites for ore usually are in areas of low mean stress, of tensile or shear failure, within large strain zones or in areas of tensile stress. As Bateman (1942) noted, the precise nature of orebody control and genesis is unsolved in the majority of cases. However, interpretation of the effects of ground preparation and of various stages of orebody development commonly is possible from structural analysis of internal constituents of an orebody. Analysis of these concepts is applicable to many types of epigenetic orebodies as well as to sedimentary rock-hosted Au deposits.

\section{Ground Preparation}

Ground preparation refers to localized physical and chemical changes, which will later favor ore deposition and these changes are present prior to the arrival of the ore-forming fluids. This concept is distinct from that of dynamic interaction of the ore fluid with the wall rock to promote orebody development during the mineralization process. The difference between these two concepts is illustrated by the distinction proposed by Poulsen and Robert (1989) between geometric orebodies, those that are the result of intersection of the host conduit with favorable geologic elements, and kinematic orebodies, those related to active shear zones and ore development by conduit-fluid interaction. Several types of ground preparation can be recognized: (1) physical preparation of the ore conduit to enhance permeability and to prepare a 
trap site; (2) chemical preparation of a trap site or district; and (3) development of unique district-scale fabrics and trap sites due to events throughout geologic history.

\section{Changes in attitude}

Changes in strike and dip of an host conduit or bed have been shown to be favorable loci for dilation, and in a dip sense, usually are attributed to reverse or normal movement on properly oriented kinks with S or Z symmetry in the fissure plane (Connolly, 1933; Newhouse, 1940; Emmons, 1948; Brown, 1957; Lyons, 1988; Kerrich and Allison, 1978; Guha and others, 1983). Orebodies also are present in dilated shear settings or in disturbed areas of complex structures (Blanchard, 1936), such as pre-existing folds or ductile pre-ore shear zones. A special type of change in strike and dip is refraction where attitude change of the host conduit is coincident with a change in the host rock type as described by Knopf (1929) and Reid and others (1975), and discussed by Treagus (1988) and Peters (1990, 1991).

\section{Splaying}

Secondary faulting or horse-tailing also has been shown to generate tensional fields and to localize orebodies. Local mean stress reduction at the points of splay is indicated to be as high as 20 percent by Chinnery (1966a,b), and Segall and Pollard (1980) suggest that splays may be focal points for seismicity, dilation, and heat flow. Cymoid loops enclose cymoid lenses in splay systems, where two major veins are connected by shear splays to form duplex structures (Sibson, 1990). Ore commonly is in the horse between the two faults, or adjacent to the bends, close to the closure of the duplex or in proximal tensional gashes (see also, Teagle and others, 1990; Gemmel and others, 1988; and Harley and Charlesworth, 1990). Geometric complexity and multiple movements in splaying areas (Lajtai, 1969) may result in local tensile stresses (Gamond, 1987). This may encourage fluid pressure and stress gradients to develop through the fault network, enhancing permeability and channel fluid flow through the splayed parts of faults. Vein and fissure orientations based on models of Tchalenko (1968) can predict or differentiate tensional or compressional orientations in a complex array of faults or shear zones.

\section{Lithologic contacts}

Lithologic contacts influence development and distribution of orebodies. Many orebodies are present on one side or the other of lithologic contacts, and the plunge of orebodies or their internal oreshoots may coincide with the intersection of a fissure and a lithologic contact. When lithologic contacts in a layered rock sequence are offset by a fault, complex relations among the orebody and the wall rocks may develop. Lithologic contacts represent zones of contrasting competency, chemistry, thermal conductance, and porosity. Lithology may influence conduit and vein style where tensional veins are parallel to kink zone boundaries in competent units, and tension gashes or dilational veins are formed in incompetent units. Special cases of ore deposits in host structures interacting with lithologic contacts are represented by bedding plane faults and saddle reefs, as described by Behre (1937), Cox and others (1986), and Tomlinson and others (1988).

\section{Fault intersections}

Intersection of two mineralized conduits commonly results in an oreshoot (Rickard, 1902) and the oreshoot will plunge within one or both of the conduits parallel to the intersection (Penrose, 1910). The geometry, such as X, T, or Y shapes, and the angle of intersection also influence any associated hydrothermal alteration pattern and development of the orebody. Barren 
cross-faults and non-dilated fissures near orebodies form intersections that also may be collinear with the orebody plunge. Intersections favor ore deposition and increase porosity by providing larger surface areas and by increasing fracture density in a localized area to provide a zone where fluids of slightly different temperature, density, pressure, and chemistry may mix.

\section{District fabric}

Each district contains a variety of rock types that have acquired fabrics due to their unique geologic history. Orebody formation most commonly is superimposed on existing fabrics (see also, White and others, 1986; Raybould, 1976). Orebody plunge, location and tenor usually can be directly related to unique geometries that existed prior to mineralization. For example, a strong mineral or intersection lineation in the host rocks may be related to or be used by subsequent major host shear zones or also may define the plunge of some orebodies (Poulsen and Robert, 1989). In this way, mineralizing solutions and associated deformations used older fabrics. In some cases, deformation events may overprint old shear zones and the plutonic rocks intruding them. In the Carlin trend area, early isoclinal $F_{1}$ folds have been refolded to northeast-striking folds, which, in turn, have been rotated by west-northwest-striking $\mathrm{F}_{3}$ shear folds to a northwest orientation (figs. 6 , 7). Rotated northwest $F_{2}$ grain is parallel to the strike of the Carlin trend, and locally, orebodies, such as Betze, are located along $\mathrm{F}_{3}$ shear folds. The $\mathrm{F}_{2}$ folds are both northeast- and southwestdipping and when clusters of northeast-dipping folds are present, they form a weak zone to nucleate local $\mathrm{F}_{3}$ shear folds (fig. 7). Using this analysis, the location of $\mathrm{F}_{2}$ folds in upper-plate rocks facilitates targeting of favorable $\mathrm{F}_{3}$ structures hidden in the lower-plate rocks.

\section{Predictable distances}

In some districts orebodies form at specific empirically predictable distances away from geologic contacts or along conduits. Spatial punctuation or periodicity also may be present between orebodies and host conduits that define patterns (Petersen, 1990; Campbell, 1990). Gradients due to temperature, pressure, or fluid chemistry can be applied to the geometries found in orebodies in terms of metal ratio contours to explain predictable distances (Petersen and others, 1977; Loucks and Petersen, 1988). Examples include those occurrences where orebodies lie a distinct and predictable distance from a contact along a host conduit or where ore pods lie certain predictable distances apart as discussed by Kutina and others (1967). Predictable distances are traditionally empiric; qualitative concepts used in ore districts and may not reflect recognized geologic processes (fig. 8A).

\section{Stacking}

In many ore districts orebodies tend to "stack up" or to be aligned along specific, predictable orientations from one host conduit to another (see also, Dickinson, 1942, 1944). Cross faulting, folding or other structural features also may be aligned along the stacking direction; however, this direction, like predictable distance, is an empirical or qualitative concept and the link to geologic features or processes may be weak or, in some cases, lacking. Stacking can take place in more than one plane (fig. 8B). Horizontal spatial periodicity or stacking of orebodies in an ore conduit can be quantified as the development ratio, which is defined by the total strike length of the conduit divided by the length of orebodies along that horizon. A typical use of the development ratio is used in old mining districts to measure how much underground development might be necessary along a favorable geologic feature to expose a number of orebodies, on the basis of previous production (drifts/stopes). The development ratio usually differs from one conduit to another within and between ore districts. 


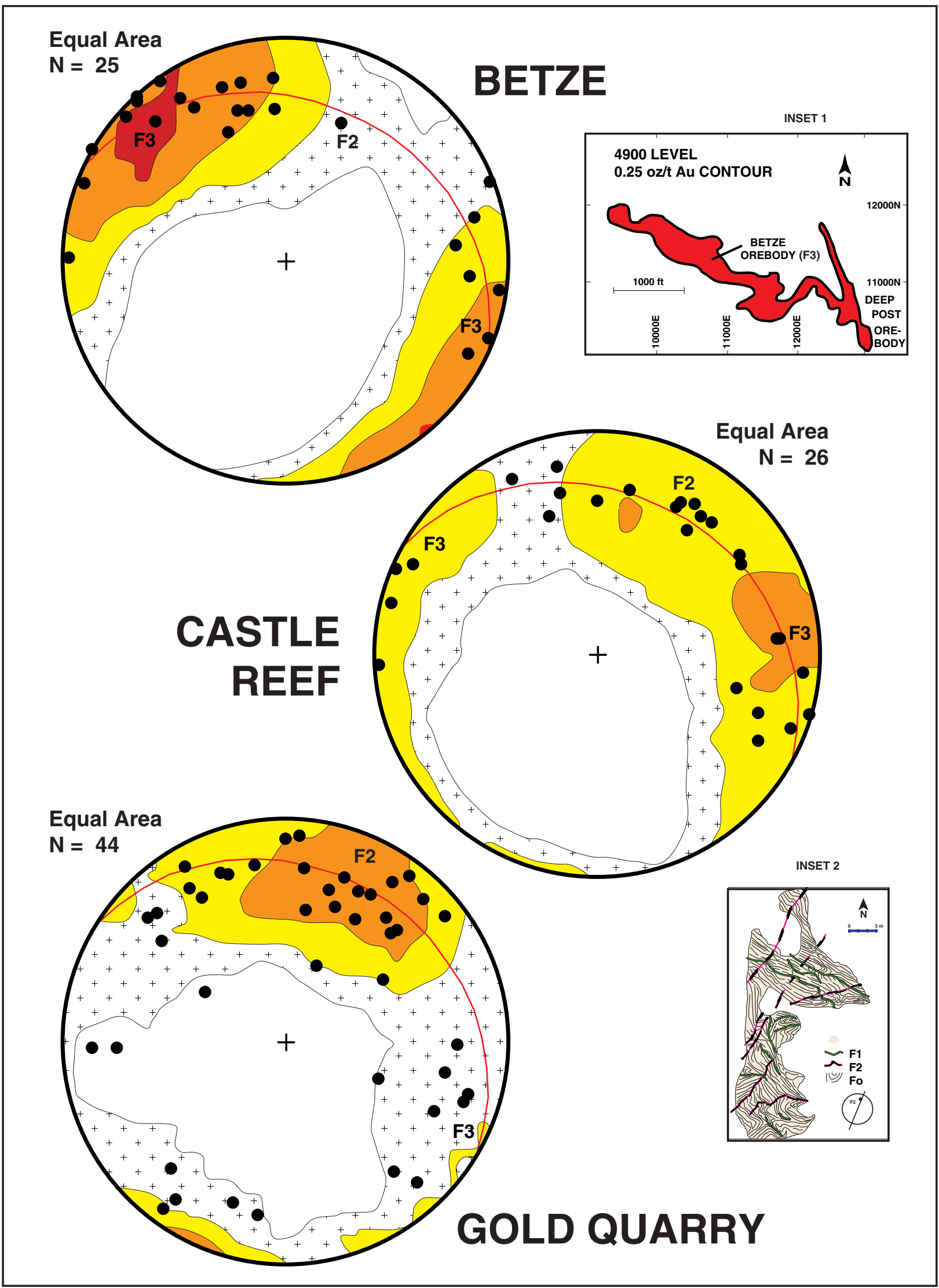

Figure 6. Examples of development of district structural grain along the Carlin trend. Three equal area stereonets show contoured fold axes from north to south at the Betze deposit, Gold Strike Mine, to the Castle Reef Fault zone south of the Carlin Mine, and Gold Quarry Mine. These three areas have northeast- and southwest-trending F2 fold axes that have been rotated to the westnorthwest and to the east-southeast along F3 shear folds (shown in red). Inset 1 shows the west northwest-striking Dillon deformation zone, which is a F3 structure. Inset 2 shows the relations among F0, F1 and F2 surfaces in chert on the west side of the Lynn window. These structural data illustrate how regional deformation affects location of orebodies. (For explanation, see Peters, 1997; Peters and others, 1998). 

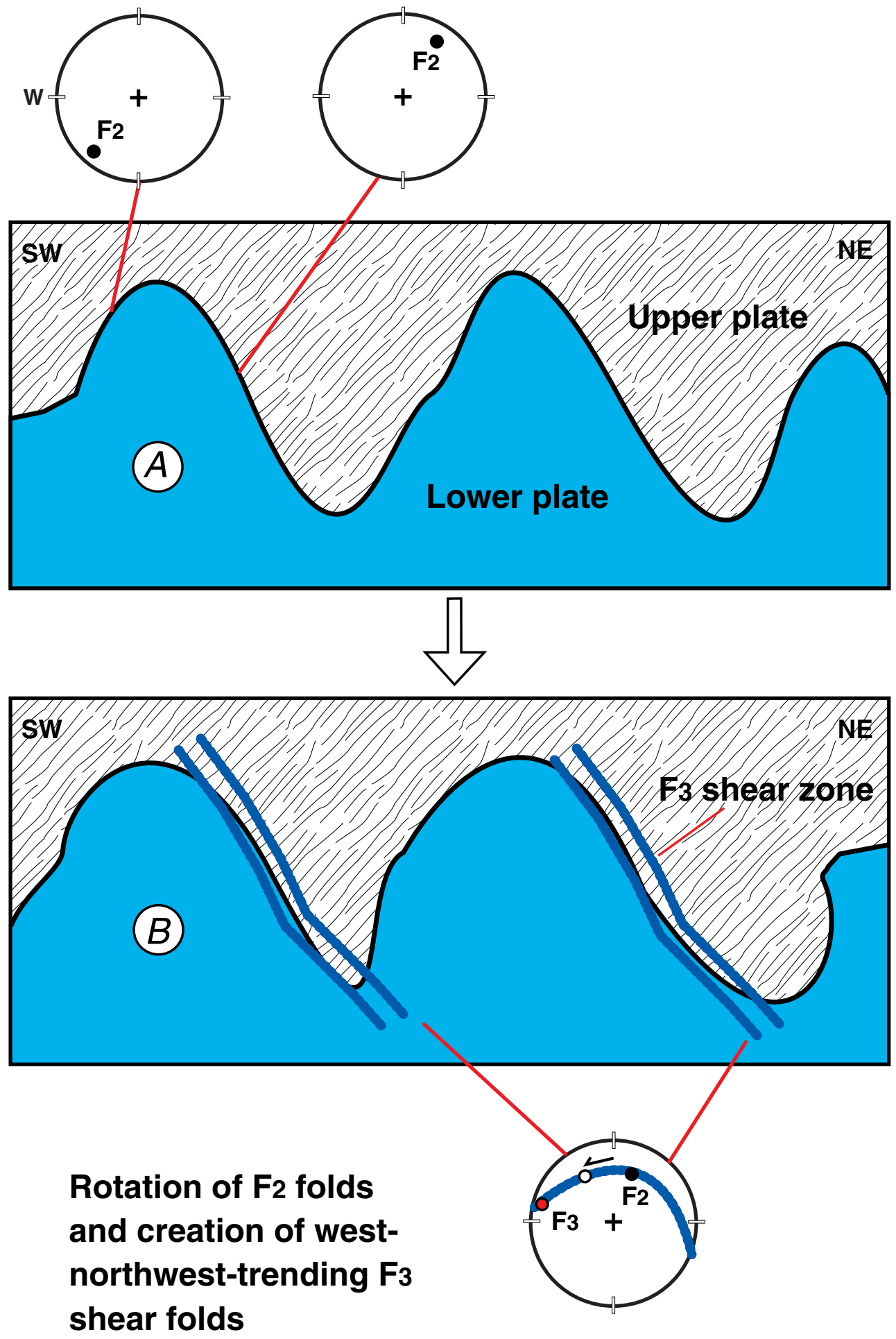

Figure 7. Diagrammatic illustration of how structural grain in the Carlin trend area (developed in Figure 6) can be used to locate hidden orebodies beneath a tectonic plate. (A) The upper and lower tectonic plate is folded by $\mathrm{F} 2$ folding that has southwest- and north-east striking fold axes. $(B)$ The northeaststriking fold axes are coplanar with F3 shear folds, and when present, form the nucleation zones for development of these shear folds. Belts of north-east-striking fold axes in the upper plate rocks may be promising zones for the development of F3 shear folds, which are known to host ore. 

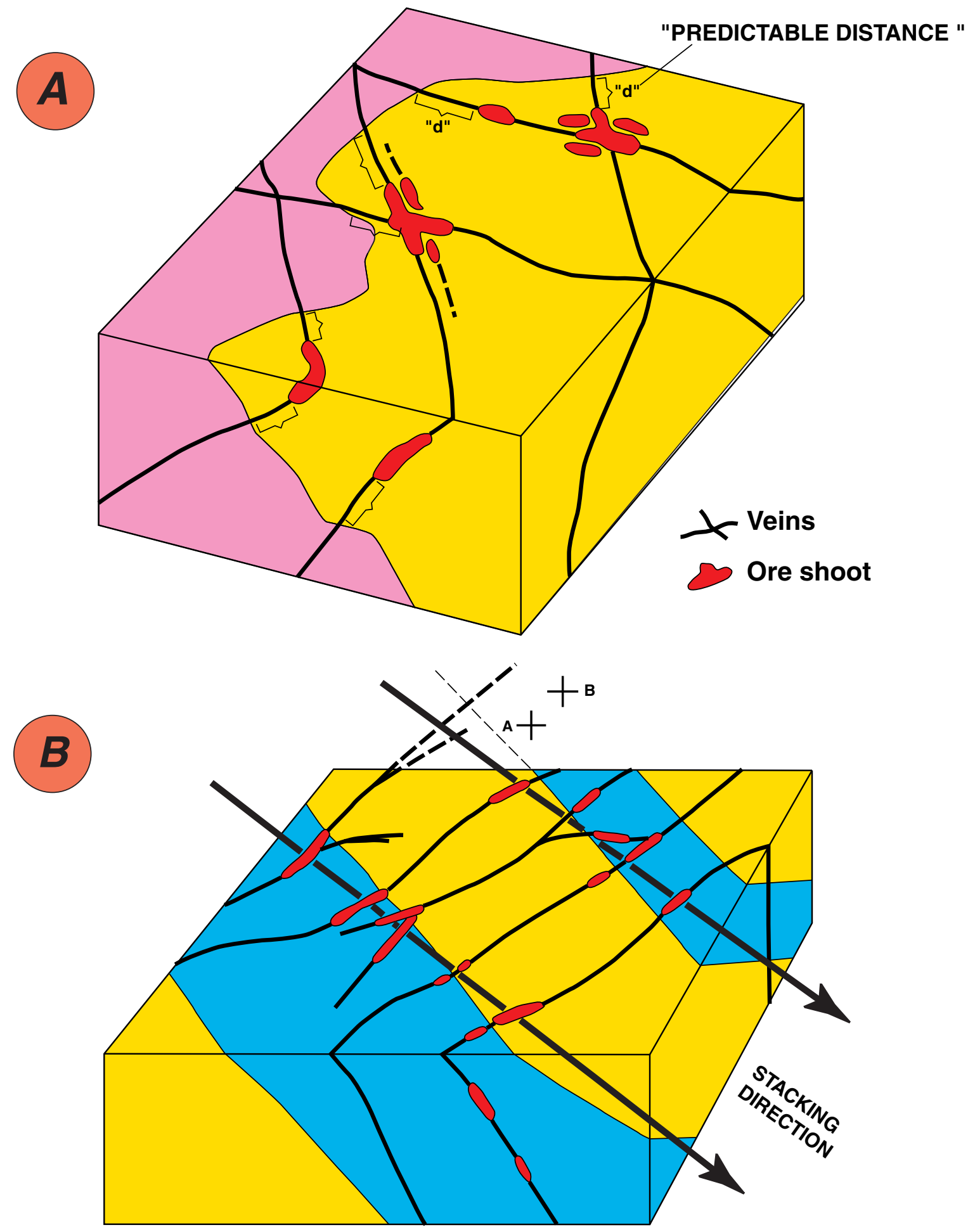

Figure 8. Conceptual controls of orebody locations. (A) Sketch of predictable distance in an hypothetical area with two rock types and two vein directions. Oreshoots tend to occur in shale (dashes) typically a distance "d" in from the granite contact. The concept of predictable distance is empiric and does not imply process. (B) Sketch illustrating stacking direction in an area with a layered sequence of rocks with crossing shear zones. Ore zones cluster where these shear zones cross sandstone (no pattern) - shale (dashes) contacts. Location of the orebodies straddles the contact, however. For instance, point A would be a more likely location for the next oreshoot, rather than point B. Stacking is an empirical concept and may defy structural analysis. It also is three dimensional. 


\section{DISTRICT-SCALE CONTROLS}

Location and geometry of orebodies at a district scale can be predicted by using a number of qualitative concepts such as internal and external plunges, district plunge, district stacking, conduit classification, gradients, and tectonic warps. These concepts have practical application in most districts in exploration for and production of ore, but are of such broad and general application that they can rarely be explained definitively. These concepts are, in many ways, district-scale equivalents of those used on the orebody-scale and they describe different predictable ways in which entire clusters of orebodies display geometric patterns.

Within a single conduit or lode, orebodies may cluster in such a way that individual orebodies plunge in one direction (internal plunge) but the overall cluster may plunge in another direction (external plunge) (Peters, 1993b). District plunge is defined when orebodies or clusters of orebodies stack or plunge in predictable geometries, as with the orebodies. An example is the overall northwest, gentle plunge of orebodies in the north-central Carlin trend, although individual orebodies may have different internal plunges (Peters and others, 1998). When similar geometries are present, a district plunge can be described and may point to a control of stratigraphy or indicate the source or pathway of ore fluids within the district. This concept can be used to predict blind (non-outcropping) undiscovered ore districts or repetition of ore clusters at depth. District stacking is present when orebodies cluster and plunge as a group. These groups may be repeated or stacked along predictable directions if the same conditions exist away from the original cluster. An example of repetition of geologic conditions might be a second favorable host rock such as a sedimentary or volcanic unit, or a secondary cross fault, parallel to the known controlling cross fault.

Deep faults may guide fluid flow from depth to the orebody environment and act as high permeability conduits as suggested by Ethridge and others (1983). Stacking of different conduits or parts of conduits may represent areas of fluid flow along separate conduits that are connected at depth. General mineralization characteristics are similar in each stacked part of a district, orebody, or oreshoot cluster, but differences in tenor and strength and structural control between them may be due to local structural and chemical conditions because of separate fluid evolution that developed along each conduit. Fluid evolution rate is dependent on the depth of separation from a parent fluid and the disequilibrium of that fluid with the wall rock. These $>1-\mathrm{km}$-scale geometric flow paths allow different or later fluids to selectively enter an ore district through separate conduits (fig. 9), which allows isolated avenues of fluid flow in a single ore district and therefore accommodates and spatially partitions separate metallogenic episodes, if they are present (Peters, 1991).

\section{Conduit classification}

Multiple conduits that feed and lie in ore districts may have different characteristics, some of which were more conducive to orebody formation than others. Many orebodies contain long strike lengths, which exhibit fabrics and other signs of shear movement (see also, Ramsay, 1980). Other orebodies contain shorter strike lengths and are contained in auxiliary extension or tension conduits (Ramsay and Huber, 1983), such as spur, link, or caunter structures (Peters, 1993b). A tendency develops for orebodies to be present in tensional structures where fluid flow and porosity is increased. Exploration and mapping techniques, such as low-level soil and rock geochemistry, alteration studies, joint density studies, as well as systematic sampling of different host conduit orientations, allow discrimination in a district or orebody of which areas or conduit orientations had the greatest fluid flow. These high-flow areas may be synonymous with or are separate from traps or areas where the fluids precipitated concentrated metals in orebodies. 


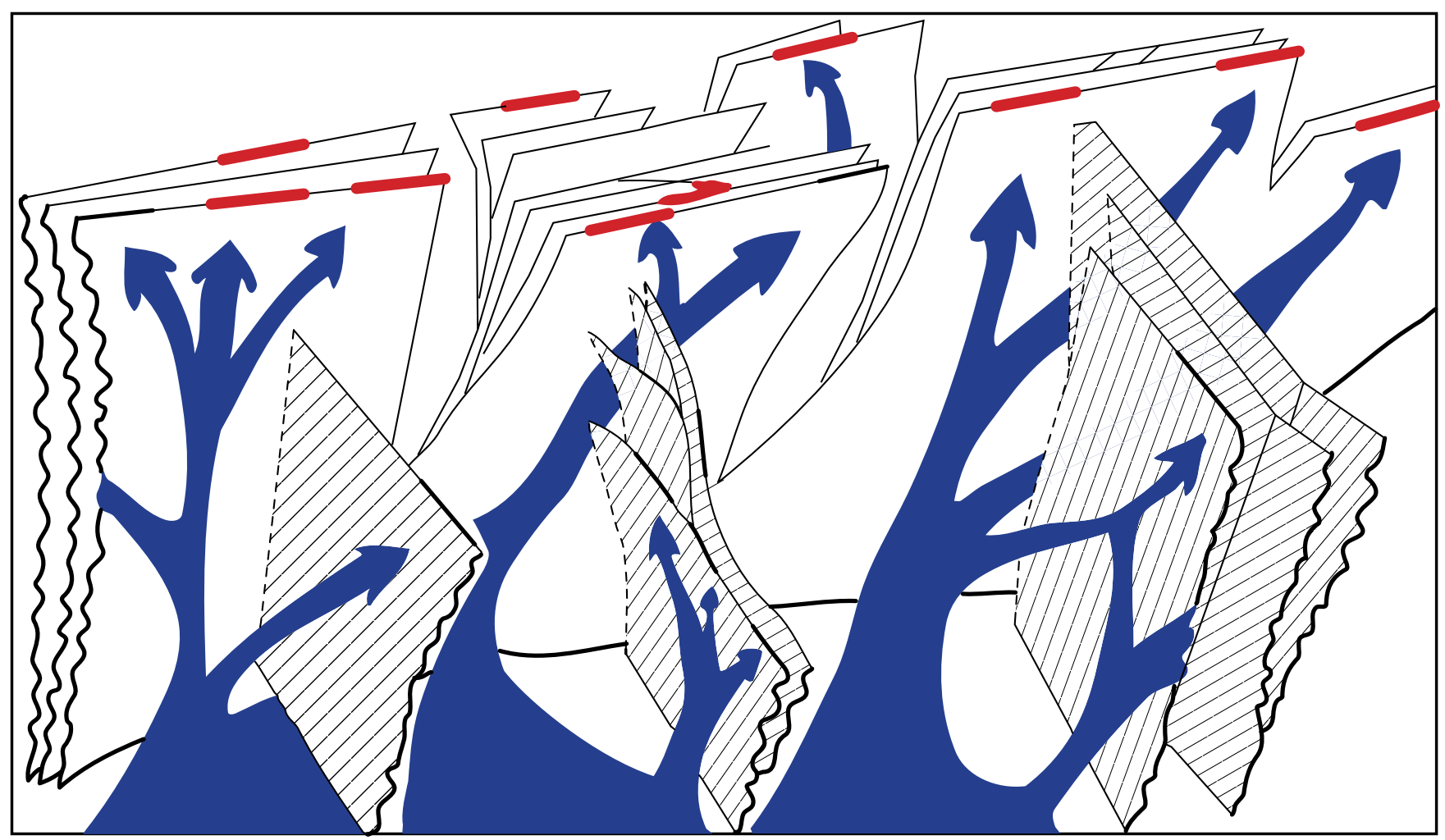

Figure 9. Model of fluid flow and cause of district ore-type variation. Sketch of penetrative shear zones or cleavage that act as conduits, which channel mineralizing fluid. Perpendicular planes (hatched) represent axial planes or other shear zones in adjacent rocks. As fluid enters these penetrative fabrics, separation take place. This allows for separate evolution of a once-homogeneous fluid due to sitespecific wall rock interaction and to localized thermal and chemical gradients. Post-Au tectonic and metallogenic events may preferentially remobilize or dialate only one fabric and thereby additional metallogenic events may overprint one orintation earlier mineralized rock, but not the other (modified from Peters, 1991,1993a). 
Many regional-scale lineaments, including district-scale faults and shear zones, appear to have been active before, during, and after the $\mathrm{Au}$ event that formed sedimentary rock-hosted $\mathrm{Au}$ deposits (fig. 10). In addition to mineral belts and their accompanying folds and faults, examples of probable regional-scale hydrothermal fluid conduits are: (1) permeable Paleozoic carbonate-rich stratigraphic units; (2) the siliciclastic-carbonate tectonic boundaries or unconformities; and (3) regional-scale tectonic zones and associated faults (fig. 10) Fluids may have traversed more than $10 \mathrm{~km}$ along some permeable or structurally prepared horızons, especially in or adjacent to districtscale tectonic lineaments that cross a number of lithostratigraphic terranes (fig. 11). Fluid flow, accompanied by deformation along structures, produces jasperoidal rocks, silicified breccia, gouge, and phyllonite along or adjacent to these structures.

Identification of district- or regional-scale conduits is important for ore discovery, because hot saline ore fluids capable of traveling distances of over $100 \mathrm{~km}$ with metals have been described by Sverjensky (1984) in sedimentary basin settings similar to those where sedimentary rock-hosted $\mathrm{Au}$ deposits are present in north-central Nevada. Applying these concepts to Nevada, much rock traversed by such fluids would be through porous, calcareous, lower plate rocks below the Roberts Mountains allochthon (figs. 10, 4D). If the ore fluid had a composition similar to that described by Woitsekhowskaya and Peters (1998), and was capable of producing sedimentary rock-hosted Au deposits, it could retain metals in solution and be able to transport metals over regional-scale distances within these rocks, due to the large buffering capacity of the carbonate in the rocks (see Crerar and others, 1985). Such fluid flow would channel into high permeability conduits and could be accompanied by deformation, coeval dissolution, magmatism, and elevated crustal heat flow (Peters, 1998, 2000) (fig. 11).

\section{Gradients}

As fluids flow through or up a conduit they move from one geologic environment to another. Changes in fluid chemistry, temperature, or pressure are responsible for precipitation of ore and gangue minerals (see also, Edwards and Atkinson, 1986). These changes of environment can sometimes be correlated directly with lithologic contacts, metamorphic grade or with other geologic parameters. Gradients in strain, porosity, temperature, pressure, and chemistry can be caused by metamorphism, rock type changes, faulting or shear zone movement, folding, magmatism, change in fluid flow rates, or other factors (see also, Henley and others, 1976; Kerrich, 1986). Magnitude and spatial patterns of gradients, in relation to host conduits on a district scale, are important factors in the distribution of orebodies. Gradient location may repeat within a district and be responsible for district plunges and district stacking.

\section{Tectonic warps}

Broad, district-scale, gentle folding locally may be superimposed upon host rocks and ore districts and may dilate large areas of the crust, similar to kilometer-scale dilatant zones, which trap oil and gas deposits. Tectonic warps in ore district may be up to 5 to $10 \mathrm{~km}$ in size and commonly develop late in orogenic cycles and usually follow older, tighter folding or shear zone development (Peters, 1993b). These earlier structures are dilated by late tectonic warping (see also, Resnell, 1990). Warped zones can be identified in ore districts by interpreting district rock and alteration distribution, contact shapes, and fold symmetries. Tectonic warps may explain why one part of a conduit is mineralized but another part is not, because only parts of the district have been dilated. Geometry of dilation zones due to warping, such as dilation refraction or partitioning through lithologic or structural regimes can also explain and predict district-scale stacking. 

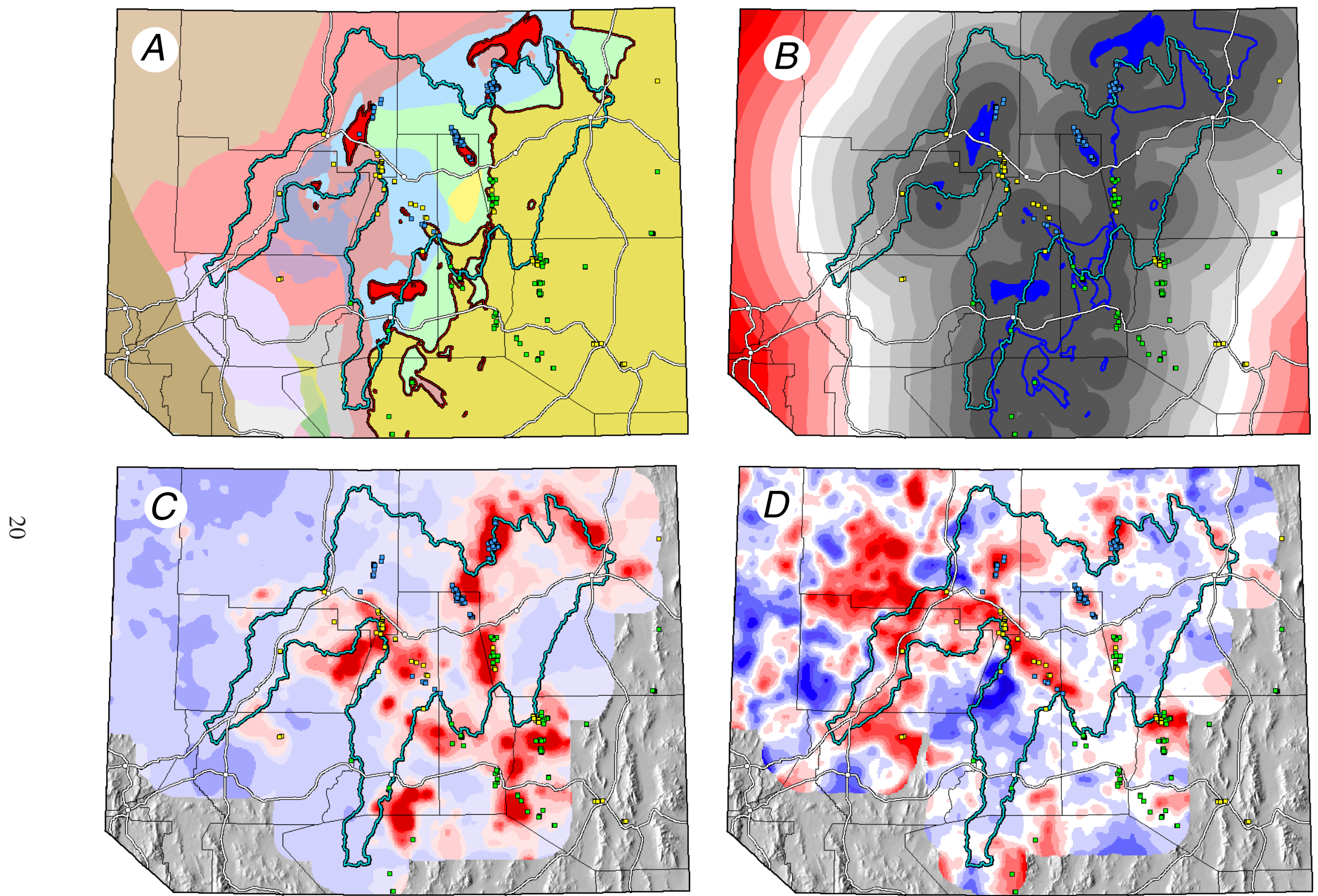

Figure 10. Examples of regional-scale conduits and structures portrayed by various data types in northern Nevada. $(A)$ Lithotectonic terranes $(B)$ Buffers around Roberts Mountains thrust. (C) Ba/Na NURE stream geochemistry. $(D)$ Arsenic NURE stream Geochemistry. Sedimentary rock-hosted Au deposits as yellow, blue and green small boxes. Coordinates and explanation in Peters and others (2001). 


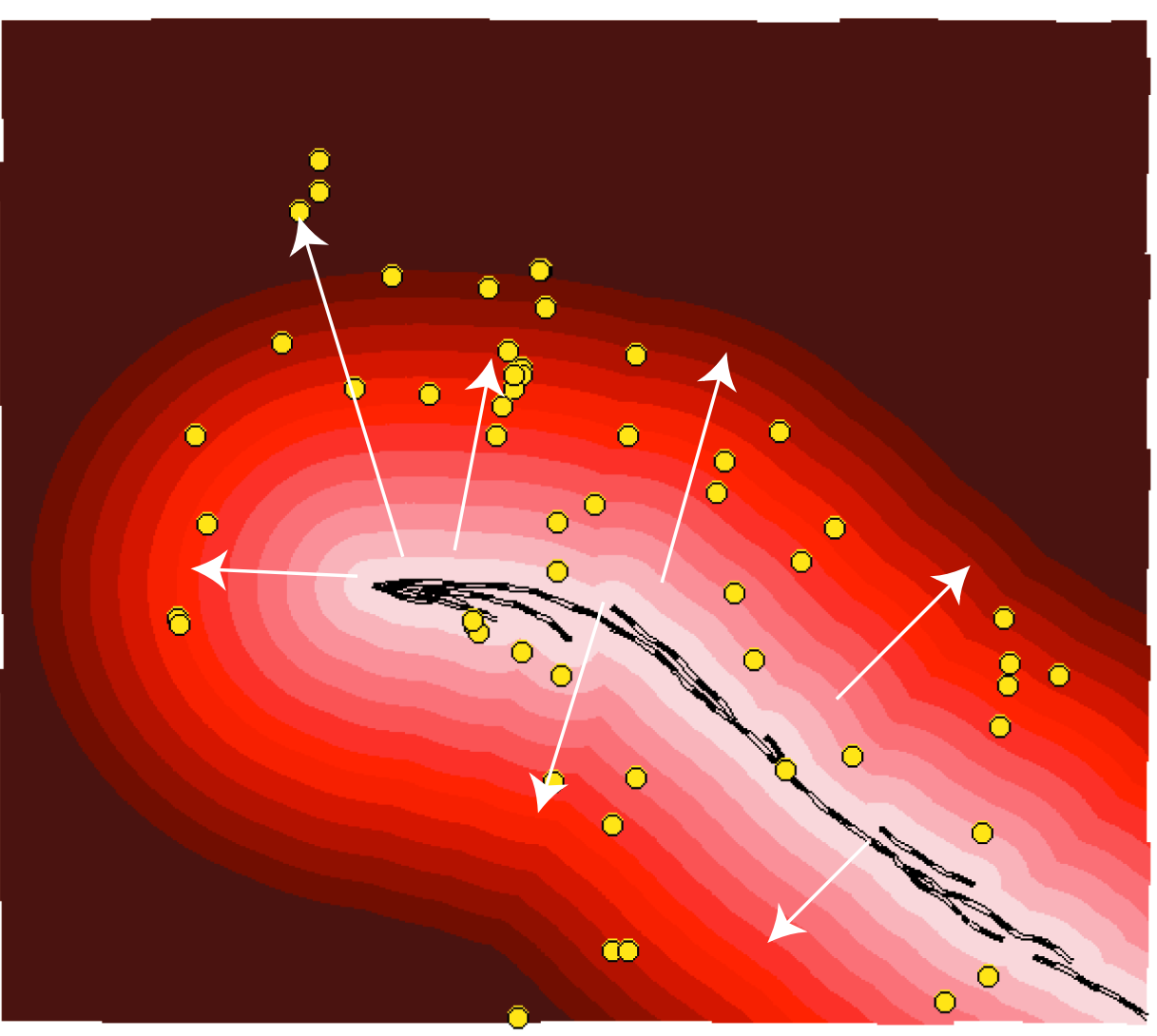

105

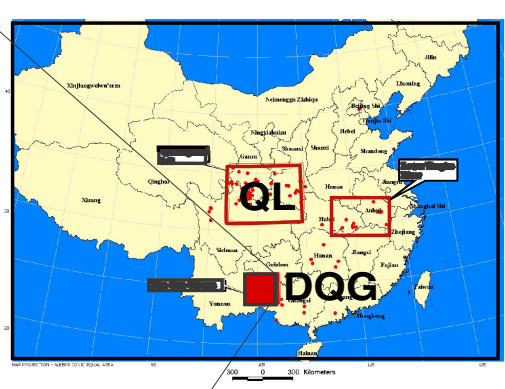

Location of Dian-Qian-Gui area in China (solid box). Other squares show location of other sedimentary rockhosted Au deposit areas.

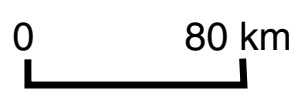

O Sedimentary rock-hosted Au deposit

Figure 11. Regional geologic and structural control of sedimentary rock-hosted Au deposits (circles) in the Dian-Qian-Gui area, P.R. China. A 100-km-wide buffer around the northwest-striking Youjiang fault zone (bold line) encompasses most of the sedimentary rock-hosted Au deposits. The shape of the cluster of deposits closely follows the shape of the graduated buffer suggesting that the deposits may be related to the fault zone. One possible theory is that fluid emanated from the fault zone (arrows) along northeast-striking faults and then was guided to individual ore deposits near structural domes. This process may be similar to fluid flow around and along the Crescent Valley-Independence lineament (Peters, 1998) in northern Nevada. Modified from Peters and others (2001a). 


\section{OROGENIC SEDIMENTARY ROCK-HOSTED AU DEPOSITS}

Close spatial relation among some sedimentary rock-hosted Au deposits and their host structures suggests that the structures and the orebodies are genetically linked because they may have shared the same developmental history. Structural and hydrothermal events are derived from similar tectonothermal mechanisms and therefore commonly have undergone similar evolutionary processes. Potential for a Au occurrence in a fault with multiple activity stages is significantly greater than that of a fault with a single stage of activity (Luo, X.H., 1994).

Peters $(1998,2000)$ has suggested that $F_{3}$ shear folding of pre-existing regional folds was a major ore-control in the large Betze deposit in the Carlin trend and that some deformation was synchronous with ore deposition. Syn-deformational genesis also has been documented in the Lannigou Au deposit, Guizhou Province, Dina-Qian-Gui region, China by Luo, X.H. (1993, 1996; Li, Z.P. and Peters, 1998) and also is suggested from ore textures in the Jinlongshan and Maanqiao Au deposits in the Qin Ling fold belt area (Peters and others, 2001b).

\section{Lannigou}

At the Lannigou Au deposit, the largest Carlin-type Au deposit in China (Li and Peters, 1998), structural movement and deformation is not only a mechanical process, but also involved a chemical process that directly and indirectly affected formation of sedimentary rock-hosted $\mathrm{Au}$ deposits (see also, Peters and others, 2001a). Evidence of syn-deformational ore deposition is contained in textural phacoidal blocks in the host shear zones surrounded by phyllonite and multiple stage breccias that contain repeated Au-related deposition (fig. 12), According to Chen Y.M. (1987) these syn-deformational processes concentrated scattered ore-related chemical elements from source strata into the Au ore deposit and also altered the existing orebody and caused enrichment or impoverishment of metals. In the Lannigou Au deposit, regional-scale structures and thermal events are postulated to have provided the heat-source and ore-forming environment for the deposit, where faults produced local traps and space for the orebodies (see also, Luo, X.H., 1993, 1994, 1996) fig. 11),

\section{Betze}

At the Betze deposit in northern Nevada, the orebody is composed of individual highgrade oreshoots that contain different geologic, mineralogic, and textural characteristics (Peters, 1996; Peters and others, 1978). The orebody is typical of many structurally controlled Carlintype deposits, and is hosted in thin-bedded, impure carbonate or limy siltstone, breccia bodies, and intrusive or calc-silicate rock. Many ores in the Betze orebody are highly sheared or brecciated and show evidence of syn-deformational hydrothermal deposition (figs. 4, 13 and 14 . Interplay between rock types and pre- and syn-structural events accounts for most of the distribution and zoning of the oreshoots. Hydrothermal alteration is scale-dependent, either in broad, pervasive alteration patterns, or in areas related to various oreshoots. Alteration includes decarbonatization ( decalcification) of carbonate units, argillization (illite-clay), and silicification. Patterns of alteration zoning in and surrounding the Betze orebody define a large porous, dilated volume of rock where high fluid flow predominated. Local restriction of alteration to narrow illite- and clay-rich selvages around unaltered phacoidal marble or calcsilicate rock masses implies that fluid flow favored permeable structures and deformed zones. 

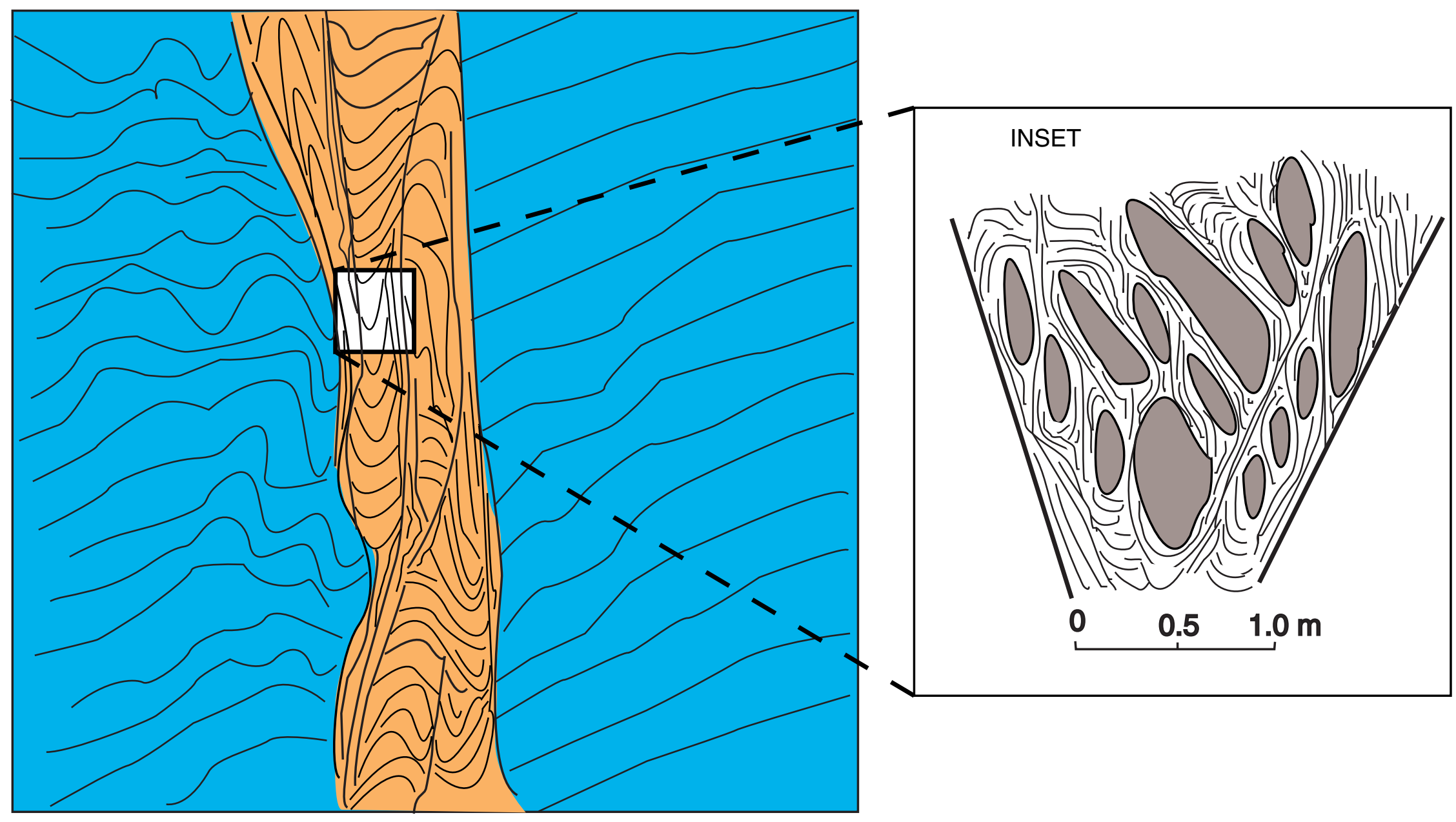

Figure 12. Schematic sketches of phacoid development along Main No. 1 shear zone (F3 fault) in the Lannigou Au deposit, Guizhou Province, Dian-Qian-Gui area, China. Shear zone is up to $100 \mathrm{~m}$ wide and contains distorted, deformed, attenuated, and folded bedding. Bedding external to the the shear zone is disturbed on the northern side. Inside the shear zone the rock is dismembered and local phyllonitic seams and clay-gouge seams surround local phacoidal shapes (inset from Luo, X.H., 1994; adapted from Li and Peters, 1998; Peters and others, 2001a). 


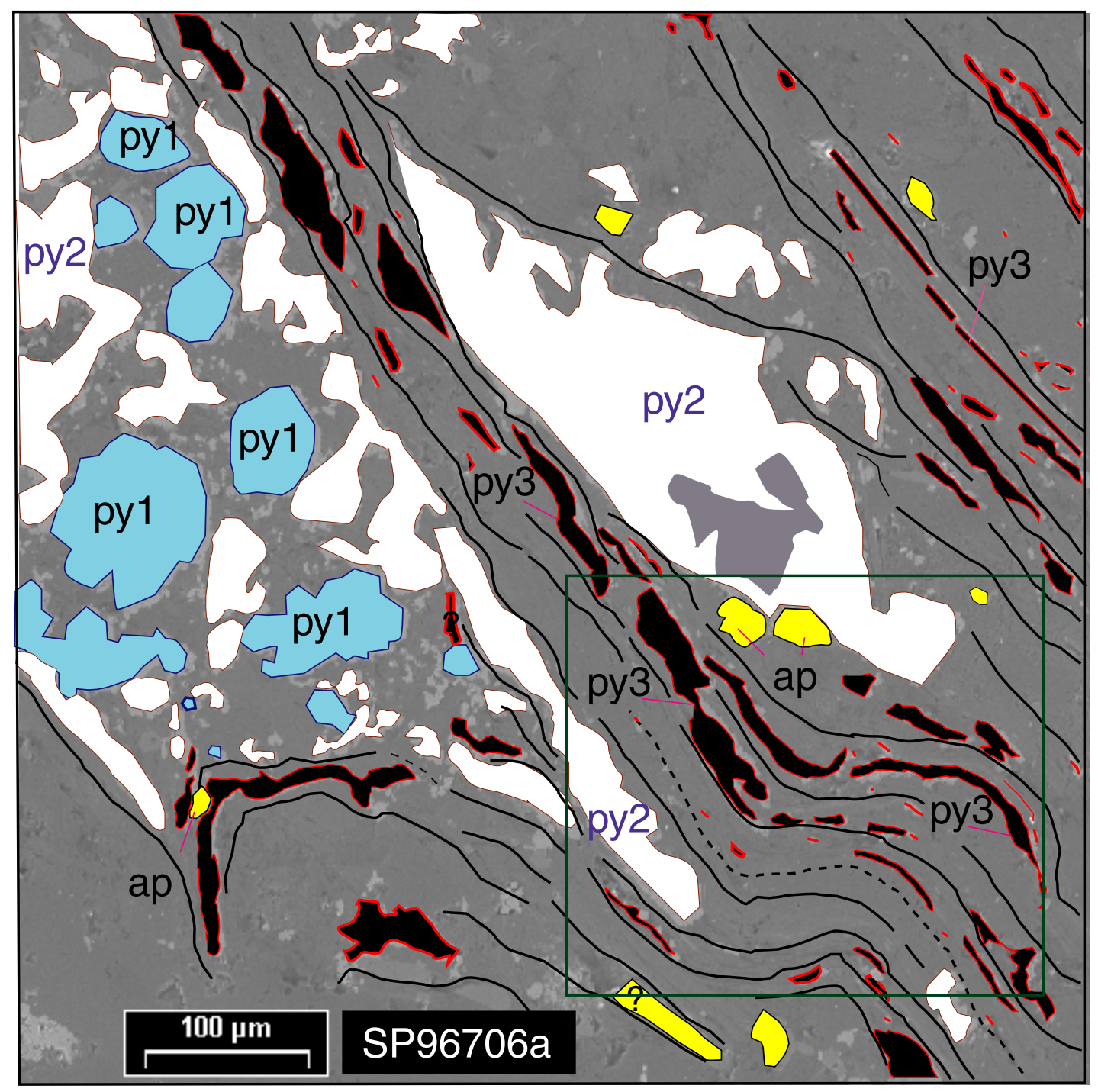

Figure 13. Multiple generations of As-rich (Au-bearing?) pyrite in microshears in lamprophyre dike in the Betze deposit, Goldstrike Mine. Euhedral pyl is overprinted by sheared blebs of py2, both of which are overprinted by finely sheared zones of py3 that are mixed with quartz and sericite. Note also hydrothermal apatite (ap). Inset shows plain SEM backscatter image and location of insets for Figure 14

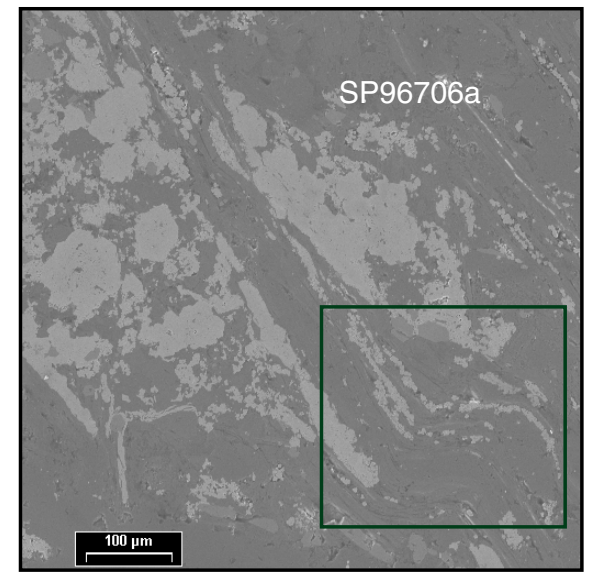



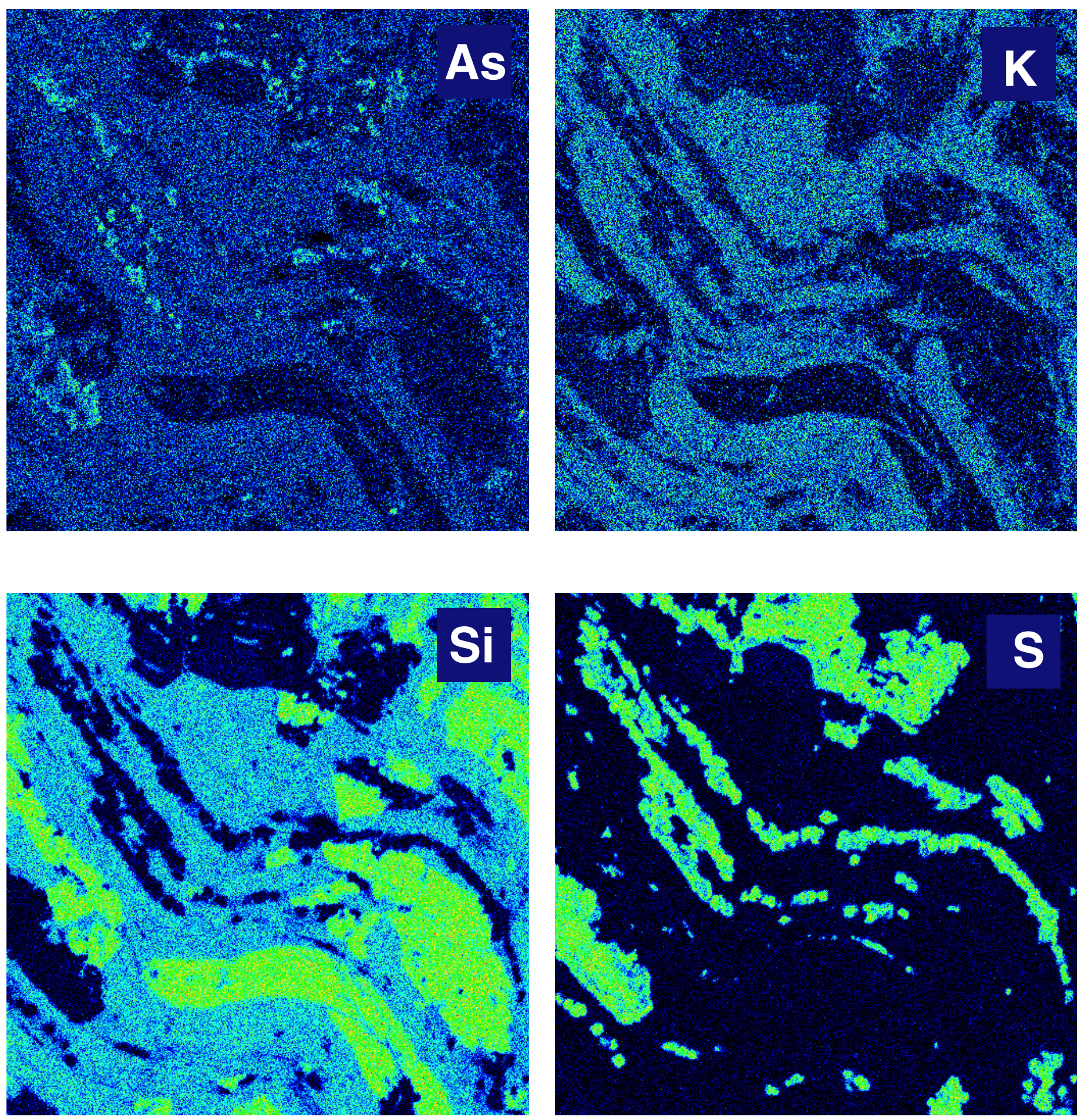

Figure 14. Element X-ray intensity SEM maps of inset in Figure 13 showing components of micro- syndeformational shear zone in lamprophyre dike in the Betze deposit. Arsenic map (As) shows enrichment in py2, but As also is present in phases py1, and py3 (see fig. 13). Potassium (K) illustrates distribution of hydrothermal sericite along shear planes that is mixed with quartz ( $\mathrm{Si}$ ). Sulfur (S) shows distribution of the three phases of pyrite. These images and the multiple breccia textures of the As-rich pyrite, suggest that the main $\mathrm{Au}$ depositional event was synchronous with deformation. 


\section{Jinlongshan}

Structures in the sedimentary rock-hosted Jinlongshan (Zhenan) Au Mining District are megascopic, anticlinal, upright, and mesoscopic recumbent folds and faults in Late Paleozoic calcareous rocks. Ore mainly is controlled along an east-west-trending anticline and commonly is hosted along east-striking, brittle-ductile shear zones containing breccia, fault gouge, and fracture networks and also is present along either the fold axes or fold limbs. Gold grade is highest at intersections of strong compressional ductile deformation zones and is most intense in places along northeast-striking fractures (Peters and others, 2001b). A pervasive cleavage $\left(S_{1}\right)$ cuts through most rocks (fig. 15). Microstructual textures in the ore outside the shear zones suggest that cleavage post-dates micro-layering of sulfide minerals along bedding, which is compatible with syngenetic, stratiform Au deposition prior to brittle-ductile shearing (figs. 15, 16) Hydrothermal alteration types include silicification, calcite veinlets and replacements, with lesser disseminations and veinlets of pyrite, arsenopyrite, barite, and kaolinite. In addition, dickite and fluorite locally are present. Gold mineralization is closely related to silica and pyrite. Supergene zones contain abundant limonite (Peters and others, 2000b).

Mineralogy in the Jinlongshan Au deposit, China, includes pyrite, arsenical pyrite, arsenopyrite, stibnite, sphalerite, and chalcopyrite. Quartz, calcite, sericite, barite, and clay minerals are the main gangue minerals. The pyrite-bearing $\mathrm{Au}$ is euhedral to subhedral along bedding planes and in dissolution-replacement zones and commonly has a growth-zoned As-rich pyrite rimmed texture fig. 17) Gold ore characteristically is massive, banded, brecciated, veinlet-disseminated, and developed in mesoscopic network structures. These textures are consistent locally with stratiform, primary syngenetic ore deposition, but also are compatible with epigenetic and superimposed orogenic processes. Zoning of As-rich and As-poor pyrite along these veinlets, suggests microbarometric control of As and (possibly) Au deposition, because As-rich zones are in sheared areas, whereas As-poor zones are in tension gashes fig. 17D). Timing of these events is not well constrained. Microscopic crosscutting relations suggest that early stratabound mineralized layers may have been remobilized by late brittle-ductile deformation, but was not affected by an earlier cleavage-forming event. A post-Au ore quartz vein event produced a series of orogenic veins and veinlets and tabular quartz matrix breccia pods and locally was synchronous with late Sb introduction (Peters and others, 2001b).

\section{Maanqiao}

The Maanqiao Au deposit in the Qin Ling fold belt, China, also has characteristics of syn-deformational, orogenic origin (Peters and others, 2000b). The deposit is hosted in Late Devonian to Late Carboniferous fine-grained clastic, carbonaceous slate and limestone units, the upper horizons of which are in contact with an early Mesozoic granite fig. 18). Contact metamorphism locally has converted the limestone to marble. Bedding planes locally have been disrupted by intense post-intrusive, bedding parallel, ductile shear zones that have dismembered many marble pods along phyllite and quartz-sericite shears. Stratabound, shear zone-hosted $\mathrm{Au}$ ore zones are surrounded by conformable, disseminated haloes of sulfide minerals in the undeformed strata around the shear zones and these halos generally are thicker than the shear zones and grade less Au than in the shear zones. Alteration consists of intense mylonitic quartzsericite-pyrite along the strands of the shear zones and is accompanied by biotite, plagioclase, ankerite, dolomite, apatite, and calcite and by disseminated non-texturally destructive growths of these minerals adjacent to the intense parts of the shear zones (fig. 19). Ore mineralogy mainly consists of pyrrhotite, pyrite, with lesser magnetite, arsenopyrite, chalcopyrite, sphalerite, galena, native $\mathrm{Au}$, local stibnite, and $\mathrm{Ni}-\mathrm{Sb}, \mathrm{Pb}-\mathrm{Cu}-\mathrm{Zn}$, and $\mathrm{Pb}-\mathrm{Sb}$ sulfide minerals. Gold mainly is present as grains of native $\mathrm{Au}$ at boundaries of metal and non-metal minerals and locally in the alteration matrix along the strands of the shear zone. 

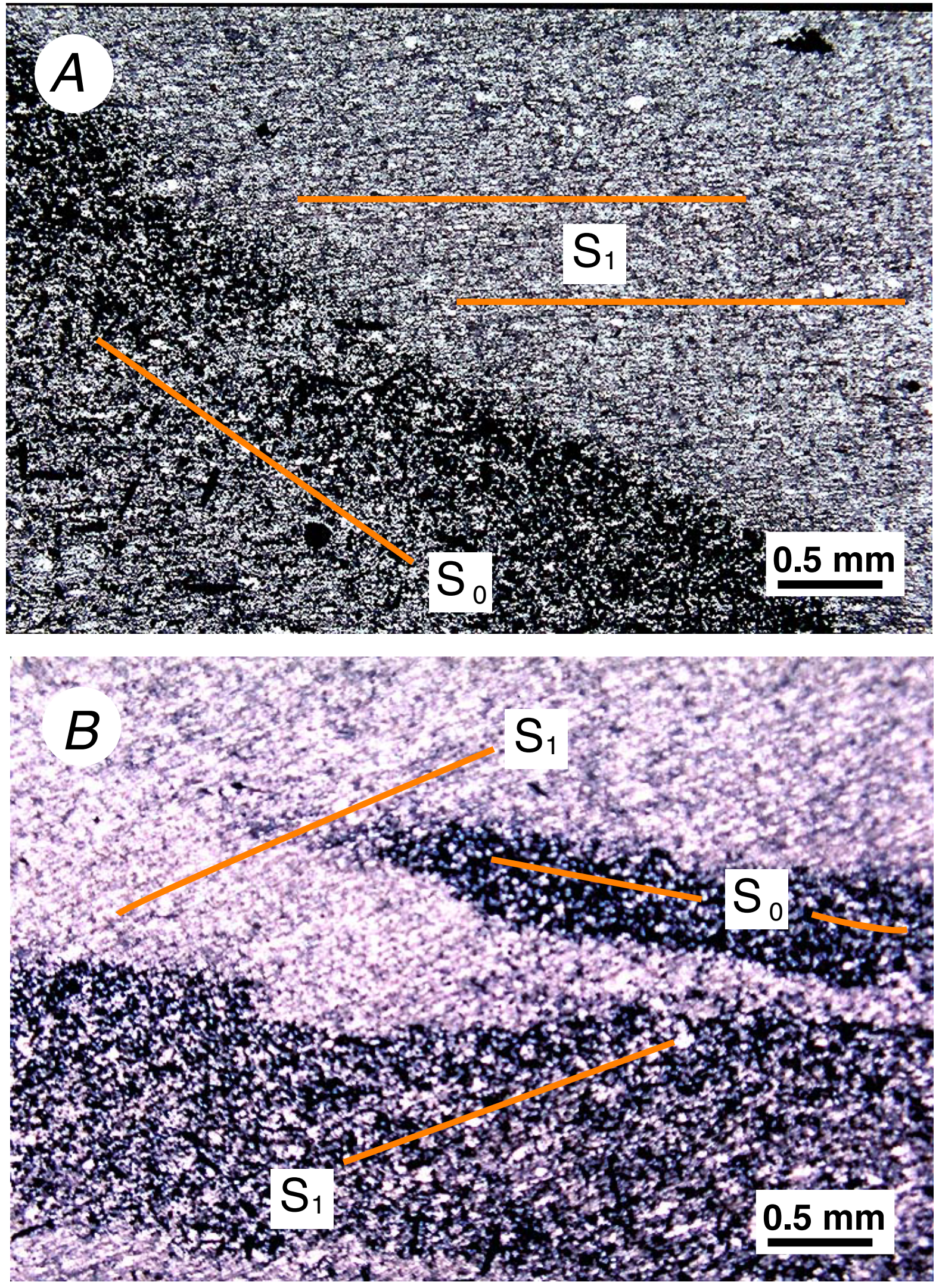

Figure 15. Microphotographs of relations among Au-pyrite, bedding, and cleavage, Jinlongshan (Zhenan) Au Mine, Shanxi Province, East Qin Ling fold belt, China. (A) Pyrite, As-rich pyrite, and arsenopyrite disseminations (darker areas) along bedding $\left(\mathrm{S}_{0}\right)$ rather than along cleavage. $(B)$ Au-mineralization also is present preferentially along bedding, rather than cleavage. These fabric relations suggest that cleavage may have post-dated Au deposition along bedding. (From Peters and others, 2001b). 

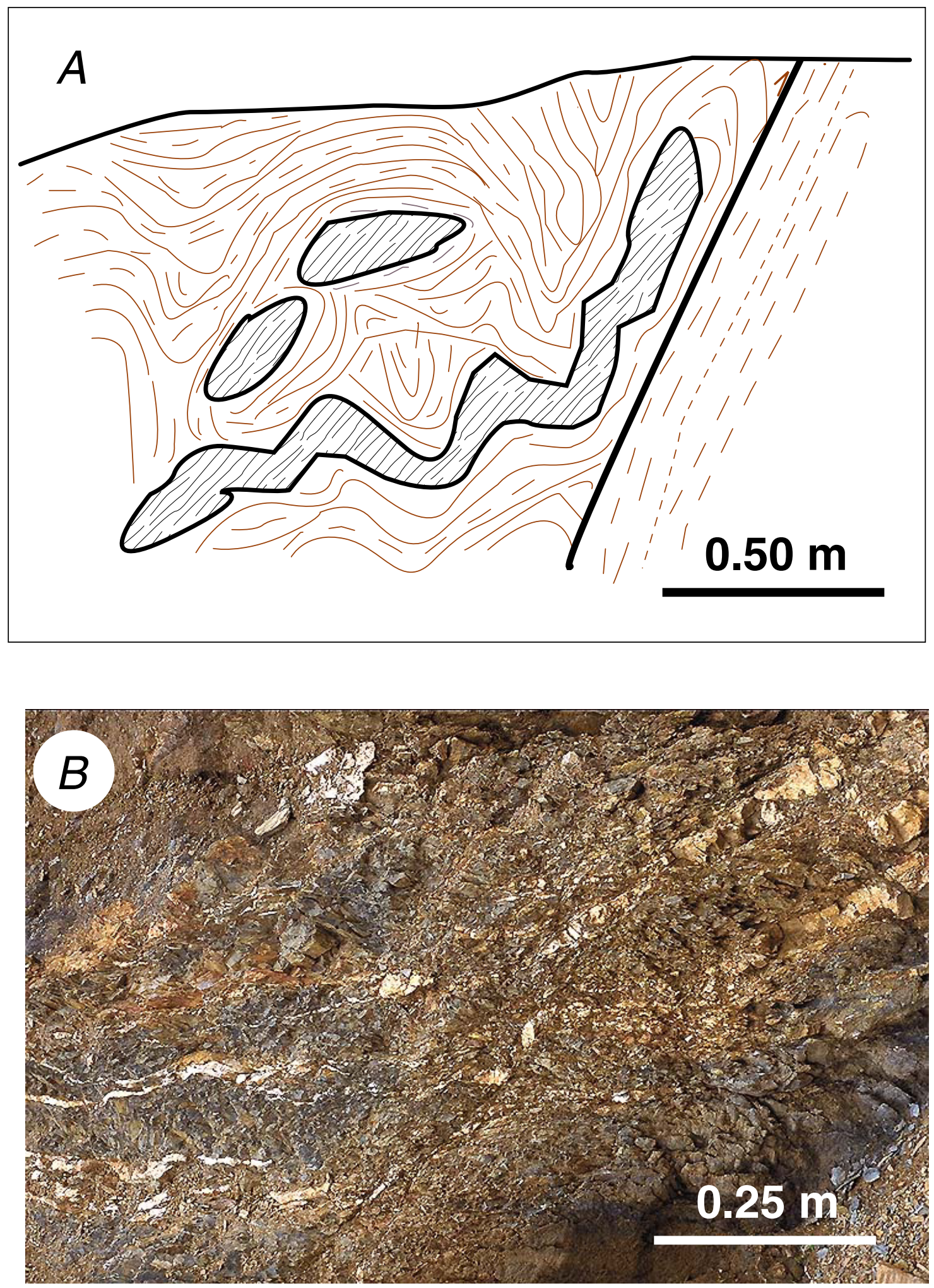

Figure 16. Mesoscopic deformation textures in the Zhenan (Jinlongshang) Au Mine area, Ding Ma Au belt, Shanxi Province, East Qin Ling fold belt, China. (A) Typical chaotic deformation textures near orebodies (sketch). Darker areas are phacoidal lenses of dismembered sandstone that are surrounded by a pelitic matrix. (B) Photograph of outcrop-scale brittle-ductile fault zone with quartz veinlets in ore zone, 304 ore body. (From Peters and others, 2001b). These textures are similar to those at Lannigou in the Dian-Qian-Gui area, China and in the Betze Au deposit, Nevada. 

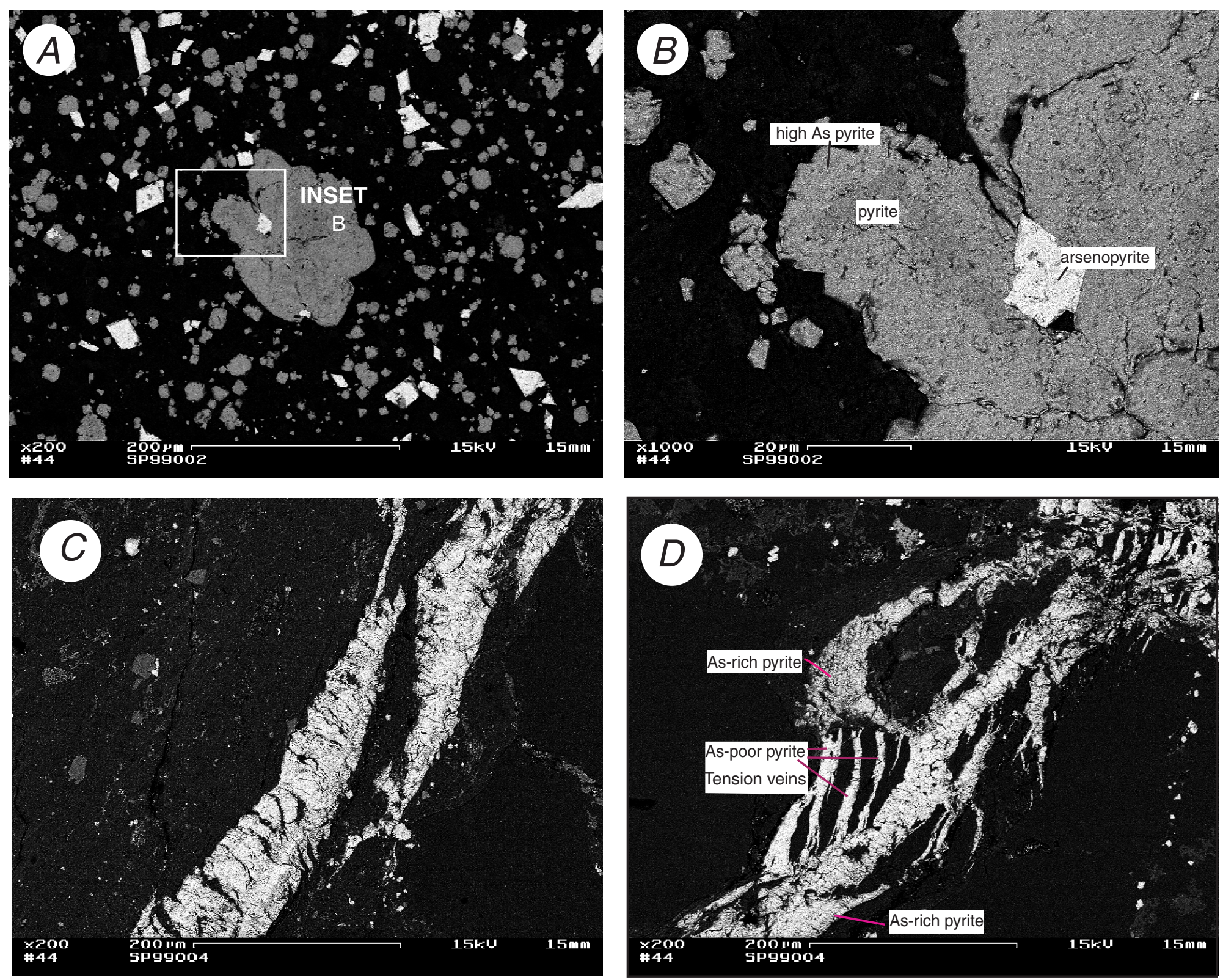

Figure 17. SEM backscatter images of As-rich pyritic ores, Jinlongshan (Zhenan) Au deposit, Ding Ma Au belt, East Qin Ling fold belt, Shanxi Province, China. (A) Pyrite and arsenopyrite. Central, large 150-mm-size pyrite is zoned with As-poor internal parts and cuspate growth rings of slightly higher As-rich pyrite. Bright, euhedral minerals are arsenopyrite. (B) Part of large 150-mm-diameter, zoned pyrite. Left lobe has zoned Aspoor interior and As-rich exterior. (C) Ductile, locally As-rich, pyrite veinlet. (D) As-rich pyrite vein injected in a ductile-brittle shear zone. Tension veinlets appear to be part of same veinlet event,but exhibit low-As, suggesting that local mm-scale pressure gradients may have affected geochemistry and deposition of pyrite phases and perhaps Au. (From Peters and others, 2001b). 


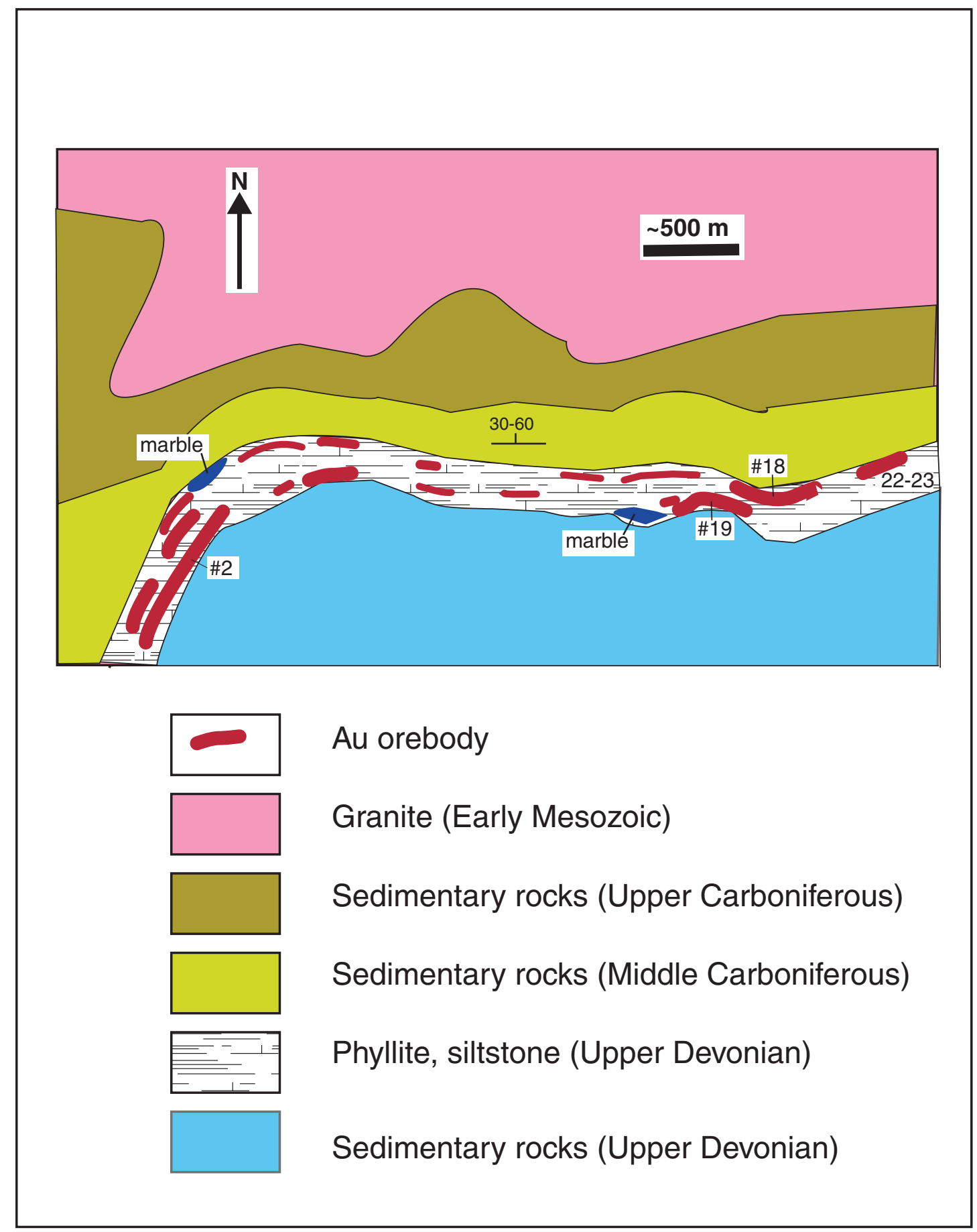

Figure 18. Plan geologic sketch of the orogenic Maanqiao Au ore bodies, Shanxi Province, East Qin Ling fold belt, China, showing stratabound nature of ore pods in mylonitized upper Devonian phyllite and siltstone. Note dismembered pods of marble along phyllitic host zone. Geochemically, this deposit is similar to many Carlin-type deposits, but has native Au. (From Peters and others, 2001b). 

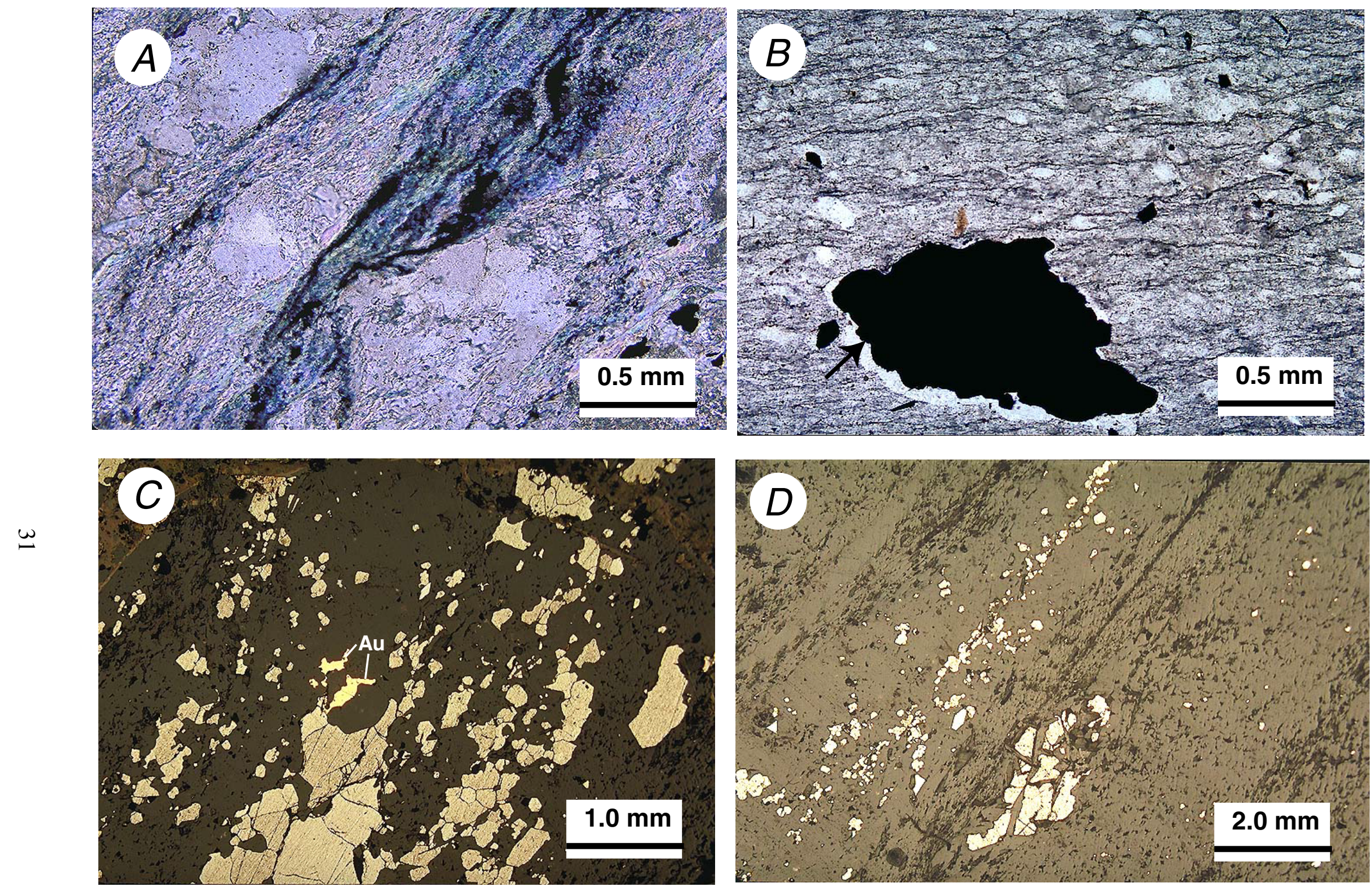

Figure 19. Microphotographs of examples of relation of sulfide minerals and Au to mylonitic foliation in the Maanqiao Au Mine, Shanxi Province, East Qin Ling fold belt. $(A)$ Elongated sulfide minerals along sericite-rich part of foliation. Crossed nicols.

$(B)$ Porphyroblastic sulfide grain with quartz-rich strain shadow (arrow) on left hand side. Crossed nicols. (C) Large mass of pyrite and pyrrhotite with Au along foliation. Reflected light. (D) Sulfide grains as porphyroblastic clusters and elongated along foliation plane. Reflected light. 
The geochemical signature of the Maanqiao Au deposit ores, consists of elevated As, $\mathrm{Sb}$, and is similar to other Carlin-type sedimentary rock-hosted Au deposits. Additional elevated concentrations of $\mathrm{Cu}, \mathrm{Pb}, \mathrm{Zn}, \mathrm{Ni}$, and $\mathrm{Co}$ also are compatible with Carlin-type deposits, but also are similar to those found in some orogenic quartz vein deposits. Locally, contents of $\mathrm{Bi}$ and $\mathrm{Ag}$ are higher in the Maanqiao Au deposit than in most other Qin Ling fold belt Carlin-type ores, but could reflect the proximity and influence of the Mesozoic intrusion to the north and inclusion of the deposit area in its contact zone.

The Maanqiao Au deposit has many similarities to orogenic shear zone-hosted Au quartz vein deposits, such as native Au, quartz-sericite alteration, and local quartz veining along the host shear zone. Some features, such as host rock, geochemistry, and geologic setting also are similar to Carlin-type deposits. The genesis of the Maanqiao Au deposit, and the similar Baguamiao Au deposit to the west, most likely is related to processes that formed the host ductile shear zones (Peters and others, 2000b).

\section{STAGES OF SYN-DEFORMATIONAL OREBODY DEVELOPMENT}

Syn-deformational, orogenic sedimentary rock-hosted $\mathrm{Au}$ orebodies present in zones of dilation and high fluid flow contain internal constituents, such as quartz, gouge, and hydrothermal alteration minerals that indicate a complex history of development. Typical growth in these types of deposits consists of four main stages: (1) ground preparation and nucleation; (2) overprinting and re-injection; (3) fault movement; and (4) consolidation, similar to those described in vein deposits by Peters (1993a). The mineralization process can be continuous throughout these four stages of growth, or it may be confined to only one stage. Complex orebodies display multiple episodes of mineralization and may grow to a relatively large size, and therefore increase the likelihood for development of high metal contents.

(1) Early ground preparation and nucleation stage involves hydrothermal alteration and dissolution, at relatively high fluid pressure - suggested on the basis of ductile fabrics and mineral textures-with resultant fluid diffusion away from a central conduit and its focusing in zones of earlier weakness, such as existing phyllonite, dikes, cleavage, or igneous apophyses. Fluid pressure also may be lowered at releasing bends (Sibson, 1990) or dilational jogs within the host conduit and therefore fluid pressure changes are a consequence of faulting rather than a trigger of faulting.

(2) A second stage of overprinting and reinjection involves wall rock assimilation and development of lode zones that are typified by major chemical transformation of the conduit. At this stage, gangue and ore-stage precipitation begins to choke the conduit in dilated zones and leads to local pressure build-ups due to backed-up fluid in the closing or confined conduit. These zones of higher fluid pressure at choke points in the conduit enhance or lead to fault movement along slip planes when the hydraulic pressure exceeds the rock strength.

(3) The fault movement stage is typified by major fault movement within the earlier prepared lode zone. This results in mechanical deformation of internal constituents of the early stages. Amount of displacement along faults is not uniform. A tendency may be present for segments of faults near orebodies to have increased displacement and this results in gouge and clay seams, as well as pods of brecciated gangue and mineralized rock mixed together. Microscopic secondary veinlets develop in cracks and sheeted zones, especially near the 
peripheries of orebodies.

(4) The consolidation stage involves growth of several connected ore zones, which may be joined together within and along the conduit into larger, composite, mature orebodies. Plucking of wall rock and older mineralized material, rotation, brecciation, and gouge development are diagnostic of this stage and responsible for complex orebody shapes.

\section{DISCUSSION AND CONCLUSIONS}

Ore genesis of sedimentary rock-hosted Au deposits in northern Nevada and China may have involved a number of possible mechanisms: (1) a single homogenous ore fluid may have traversed the region along lineaments, producing clusters of ore deposits in tectonic windows or domes that served as permeable "traps"; or (2) intersection of tectonic lineaments with district trends and windows or domes provided permeable foci that accessed deep-seated ore fluids in these localized areas; or (3) tectonism, crustal-scale hydrologic flow, and heat flow provided unique settings at different or multiple ages in each of the mining districts.

Control of large orebodies is complex where several causes of dilation usually are present. Different aspects of structural control may dominate different parts of the same orebody, may become interrelated, or may be interpreted to change with time as an orebody developed. Changes through time in development of an orebody may progress from early, broad dilation to fault movement and quartz deposition, and then to more complex interconnected conduit networks. Anatomy of orebodies is displayed at large scale by the petrology and textural relationships of the internal constituents. At smaller scales, geometric relations among orebodies in a district display unique petrologic features. Systematic documentation and analysis of geometries and textures of orebody components can result in conceptualization of processes or empiric relationships that are applicable to district appraisal and ore discovery.

\section{ACKNOWLEDGMENTS}

Access to the Betze orebody was provided by Barrick Goldstrike Mines and to other areas along the Carlin trend by Newmont Mining Co. Access to deposits in China was facilitated by the Tianjin Geological Academy of the Mining and Metallurgical Industries, and the China Gold Bureau. Ted G. Theodore and Peter Vikre provided review of the draft manuscript and their suggestions greatly improved it. 


\section{REFERENCES}

Arehart, G. B., 1996, Characteristics and origin of sediment-hosted gold deposits: a review: Ore Geology Reviews, v. 11, p. 383-403.

Arehart, G.B., Chryssoulis, S.L., and Kesler, S.E., 1993a, Gold and arsenic in iron sulfides from sedimenthosted disseminated gold deposits: Implications for depositional processes: Economic Geology, v. 88, p. 171-185.

Bakken, B.M., and Einaudi, M.T., 1986, Spatial and temporal relations between wall-rock and gold mineralization, main pit, Carlin gold mine, Nevada, in MacDonald, A.J., Gold '86, Willowdale, Ontario: Konsult International Inc., p. 388-403.

Bakken, B.M., Hochella, M.R., Jr., Marshall, A.F., and Turner, A.M., 1989, High resolution microscopy of gold in unoxidized ore from the Carlin mine, Nevada: Economic Geology, v. 84, p. 171-179.

Bateman, A. M., 1942, Economic Mineral Deposits: John Wiley and Sons, New York, 898 p.

Behre, C.H., 1937, Bedding plane faults and their economic importance: American Institute Mining Metallurgy Transactions, no. 126, p. 512-529.

Bell, T.H., 1981, Foliation development-The contribution, geometry and significance of progressive, bulk, inhomogeneous shortening: Tectonophysics, v. 75, p. 273-296.

Blanchard, R., 1931, Use of ore guides: Engineering Mining Journal, v. 131, p. 174.

Brace, W.F., 1980, Permeability of crystalline and argillaceous rocks: International Journal Rock Mechanics Mineral Science, v. 1, p. 241-251.

Bursnall, J.T. ed., 1989, Mineralization and shear zones: Geological Association Canada, Short Course Notes, no. 6: 229 p.

Byerlee, J.D. and Brace, W.F., 1972, Fault stability and pore pressure: Bulletin Seismology Society of America, v. 62, p. 656-660.

Campbell, J.D., 1990, Hidden Gold, The Central Norseman Story: Australasian Institute Mining Metallurgy, Monograph 16, 68 p.

Cathles, L., 1977, An analysis of the cooling of intrusives by ground-water convection which includes boiling. Economic Geology, 72: 804-826.

Chen, Yuanming, 1987, The discovery of the fine-grained disseminated gold deposit in southwestern Guizhou by means of geochemical methods (in Chinese): Contribution to the Exploration of Geophysics and Geochemistry, v. 5. p. 39-44.

Chinnery, M.A., 1966a, Secondary faulting I, Theoretical aspects: Canadian Journal of Earth Science, no. 3, p. 163-174.

Chinnery, M.A., 1966b, Secondary faulting II, Geological aspects: Canadian Journal of Earth Science, no. 3: $175-190$.

Clark, G.B., 1948, Geological studies can avoid costly mistakes: Engineering and Mining Journal, v. 149, p. 94-

Conolly, D. E., 1936, A contour method of revealing some ore structures: Economic Geology, no. 3, p. 259-271.

Coveney, R.M., 1981, Gold quartz veins and auriferous granite at the Oriental Mine, Allegheny district, California: Economic Geology, no. 76, p. 2,176-2,199.

Cox, S.F., Etheridge, M.A., and Wall, V.J., 1986, The role of fluids in syntectonic mass transport, and the localization of metamorphic vein-type ore deposits: Ore Geology Reviews no. 2, p. 65-86.

Crerar, D., Scott, W., and Brantley, S., 1985, Chemical controls on solubility of ore-forming minerals in hydrothermal solutions: Canadian Mineralogist, v. 23, p. 333-352.

Edwards, R. and Atkinson, K., 1986. Ore Deposit Geology: London, Chapman and Hall, 466 p.

Emmons, W.H., 1948, Certain orebodies on warped fault planes: American Institute Mining Metallurgical Engineers Transactions, no. 178, p. 58-81.

Engelder, J.T., 1974, Cataclasis and the generation of fault gouge: Geological Society America. Bulletin, v. 85 , p. $1515-1522$. 
Etheridge, M.A., Wall. V.J., and Vernon, R. H., 1983, The role of the fluid phase during regional metamorphism and deformation: Journal Metamorphic Geology, v. 1, p. 205-226.

Fleet, M.E., and Mumin, Hamid, 1997, Gold-bearing As-rich pyrite and marcasite and arsenopyrite from Carlin Trend gold deposits and laboratory studies: American Mineralogist, v. 82, p. 182187.

Fyfe, W.S., Price, W.J., and Thompson, A.B., 1978, Fluids in the Earth's Crust: Elsevier, New York, 383 p.

Gamond, J. F., 1987, Bridge structures as a sense of displacement criteria in brittle fault zones: Journal Structural Geology, v. 9, p. 609-620.

Gemmel, B. J., Simmons, S. F., and Zuntop, H., 1988. The Santo Nino silver-lead veins, Fresnillow district, Zacatecas, Mexico: Part II, Structure, vein stratigraphy, and mineralogy. Economic Geology, 83: 1597-1618.

Géraud, Yves, Caron, Jean-Michel, and Favre, Pierre, 1995, Porosity network of a ductile shear zone: Journal of Structural Geology, v. 17, no. 12, p. 1757-1769.

Guha, R., Archambault, G., and Leroy, J.M., 1983. A correlation between the evolution of mineralizing fluids and geomechanical development of a shear zone, as illustrated by the Henderson 2 mine, Quebec. Economic Geology, 78: 1605-1618.

Harley, M. and Charlesworth, E.G., 1990. Structural controls in the distribution of gold at the How Mine, Bulawayo, Zimbabwe: Economic Geology, no. 85, p. 1,697-1,710.

Hausen, D.M., and Kerr, P.F., 1966, Fine gold occurrence at Carlin, Nevada: Economic Geology, v. 61, no. 8 , p. $1,468-1,469$.

Hazen, S.W., Jr., and Gladfelter, G.W., 1964, Using unequal sample interal lengths and weighted averages in estimating grade of ore for bedded deposits: U.S. Bureau of Mines Report of Investigations 6406, $23 \mathrm{p}$.

Henderson, Q.J., 1965, The Role of the geologist in underground Mines, in Lawrence, L.J., ed., Exploration and Mining Geology, with Particular Reference to the Commonwealth of Australia: Eighth Commonwealth Mining and Metallurgical Congress Publications, vol. 2, Australasian Institute of Mining and Metallurgy, Parkville, Victoria, p. 263-267.

Henley, R. W., Norris, R. J., and Patterson, J., 1976. Multistage ore genesis in the New Zealand Geosynclines: A History of post-metamorphic lode emplacement: Mineralium Deposita, no. 11, 180-196.

Henley, R.W., 1973, Some fluid dynamics and ore genesis: Transactions Institute Mining Metallurgy, v. 82, p. B1-B8.

Henley, R.W., and Ethridge, M.A., 1994, Syn-deformational gold transport and deposition in brittle-ductile shear zones - some chaotic thoughts, in Hickman, Stephen, Sibson, Richard, and Bruhn, Ronald, eds., 1994, Proceedings of Workshop LXIII The Mechanical involvement of fluids in Faulting, 6 - 10 June, 1993: U.S. Geological Survey Open-File Report 94-228, p. 204 215.

Hewlett, R.F., 1970, Comparison of the triangular, polygonal, and a statistical method of computing grade and tonnage of ore fro the silver Bell Oxide porphyry copper deposit: U.S. bureau of Mines Report of Investigations 7331, 33 p.

Hickman, Stephen, Sibson, Richard, and Bruhn, Ronald, eds., 1994, Proceedings of Workshop LXIII The Mechanical Involvement of Fluids in Faulting, 6 - 10 June ,1993: U.S. Geological Survey Open-File Report 94-228, 615p.

Hodgson, C.J., 1989. The structure of shear-related vein-type gold deposits: A review. Ore Geol. Rev., 4: 231-273.

Hofstra, A.H., Leventhal, J.S., Northrop, H.R., Landis, G.P., Rye, R.O., Birak, D.J., and Dahl, A.R., 1991, Genesis of sediment-hosted disseminated-gold deposits by fluid mixing and sulfidization: chemical-reaction-path modeling of ore-depositional processes documented in the Jerritt Canyon district, Nevada: Geology, v. 19, p. 36-40.

Hulin, C.D., 1929, Structural control of ore deposits: Economic Geology, v. 24, p. 15-49. 
Hull, J., 1988, Thickness-displacement relationship for deformation zones: Journal Structural Geology, v. 10, p. 431-435.

Jensen, M.C., and Bateman, A. M., 1981. Economic Mineral Deposits, 3rd Ed., John Wiley and Sons, New York, $593 \mathrm{p}$.

Kerrich, R., and Allison, I., 1978. Vein geometry and hydrostatics during Yellowknife mineralization: Canadian Journal Earth Science, no. 15, p. 1,653-1,660.

Kerrich, Robert, 1986, Fluid transport in lineaments: Philosophical Transactions Royal Society London, v. A317, p. 216-251.

King, H.F., McMahon, D.W., and Bujfor, G.J., 1982, A guide to the understanding of ore reserve estimation: Australasian Institute of Mining and Metallurgy, Proceedings, No. 28, p. 1-24.

Knopf, A., 1929, The Motherlode system of California: U.S. Geological Survey Professional 157, 88 p.

Kuehn, C.A., and Rose, A.W., 1992, Geology and geochemistry of wall rock alteration at the Carlin gold deposit, Nevada: Economic Geology, v. 87, p. 1,697-1,721.

Kutina, J., Pokorny, J., and Vesela, M., 1967, Empirical prospecting net based on the regularity distribution of ore veins with application to the Jihlava mining district, Czechoslovakia: Economic Geology, no. 62, p. 390-405.

Kužvart, Milos, and Böhmer, Miloslav, 1978, Prospecting and exploration of mineral deposits: Academia, Prague, $431 \mathrm{p}$.

Kwa, B.L., and Jones, P.F.W., 1986, Mineral reserve estimation of gold deposits-A survey of practices, in David, M., Fruidevaux, R., Sinclair, A.J., and Vallée, M., eds., Ore reserve estimation methods, Models and Reality: Symposium Proceedings, May 10-11, 1986, The Canadian Institute of Mining and Metallurgy, p. 165-177.

Lahren, M.M., Schweickert, R.A., Connors, K.A., and Luddington, S., 1995, Allochthonous tectonic units of the central and western Great Basin: Geology and Ore Deposits of the America Cordillera, Reno/Sparks, Nevada, 1995, Program with Abstracts, p. A45.

Lajtai, E.Z., 1969, Mechanics of second order faults and tension gashes: Geological Society American Bulletin, v. 80, p. 2253-2272.

Leonardson, R.W., and Rahn, J.E., 1996, Geology of the Betze-Post gold deposits, Eureka County, Nevada, in Coyner, A.R., and Fahey, eds., Geology and Ore Deposits of the American Cordillera: Geological Society of Nevada, Symposium Proceedings, Reno/Sparks, Nevada, April, 1995, p. 61-94.

Li, Zhiping, and Peters, S.G 1998, Comparative Geology and Geochemistry of Sedimentary- Rock-hosted (Carlin-type) Gold deposits in the People's Republic of China and in Nevada, USA: USGS

Open-File Report 98-466, (CDRom, v. 1.1 with data base), http://geopubs.wr.usgs.gov/openfile/of98-466/. V. 1.2 updated May, 2000, March, 2001.

Lindgren, W., 1933, Mineral Deposits: McGraw Hill, New York, 930p.

Logan, J.M., and Decker, C.L., 1994, Cyclic fluid flow along faults, in Hickman, Stephen, Sibson, Richard, and Bruhn, Ronald eds., 1994, Proceedings of Workshop LXIII The Mechanical involvement of fluids in Faulting, 6 - 10 June, 1993: U.S. Geological Survey Open-File Report 94-228, p. 190-203.

Luo, Xiaohuan, 1993, Exploration of the mechanisms and features of ore-control fault (F3) and structure metallogenic processes at the Lannigou gold deposit: Guizhou Geology, v.1, no. 1, p. 26-40 (in Chinese).

1994, Geological characteristics, forming mechanism and prospect on Lannigou gold deposit in Zhengfeng county, Guizhou Province, in Liu, Dongsheng, Tan, Yunjin, Wang, Jianye and Jiang, Shufang, eds., Chinese Carlin-type Gold Deposits: University of Nanjing Press, Nanjing, p. 100-115. (in Chinese).

1996, A study on the control of geometric and kinetic features of faults structures on the location of gold deposits - example from Carlin-type gold deposits of southwest Guizhou: Guizhou Geology, v. 14, no. 1, p. 46-54, (in Chinese).

Loucks, R.R., and Petersen, U., 1988. Polymetallic epithermal fissure vein mineralization, Topia, Durango, 
Mexico: Part II. Silver Mineral chemistry and high resolution patterns at chemical zoning in veins: Economic Geology, no. 83, p. 1,529-1,559.

Lovering, T.S., 1949. Rock alteration as a guide to ore - East Tintic district, Utah, Economic Geology, Monograph 1, 64p.

Lyons, J.I., 1988. Geology and ore deposits of the Boloanos silver district, Jalisco, Mexico. Economic Geology, no. 83 , no. 1,560-1,582.

McClay, K.R., 1977, Pressure solutions and cobble creep in rocks and minerals: a review: Journal Geological Society London, v. 134, p. 570.

McKinstry, H. E., 1941, Structural control of ore deposition in fissure veins: Transactions American Institute Mining Metallurgy Technical Publication 1267, v. 144, p. 65-88.

1955, Structure of hydrothermal ore deposits: Fiftieth Anniversary Volume: Society Economic Geology, p. 170-225.

McLaughlin, D.H., and Sales, R.H., 1933, Utilization of geology by mining companies, in Ore Deposits of the Western State, The Committee on the Lindgren Volume, ed., American Institute of Mining and Metallurgical Engineers, New York, p. 683-686.

Moore, D.E., Summers, R., and Byerlee, J. D., 1989, Sliding behavior and deformation textures of heated illite gouge: Journal Structural Geology, v. 11, p. 329-342.

Newhouse, W.H., 1940. Openings due to movement along a curved or irregular fault plane, Economic Geology, 35: 445-464.

Newhouse, W.H., 1942, ed., Ore deposits as Related to Structural Features, Princeton University Press., 280 p.

O'Hara, K., 1988, Fluid flow and volume loss during mylonitization: an origin for phyllonite in an overthrust setting, North Carolina, USA. Tectonophysics, v. 156, p. 21-36.

Penrose, R.A.F., Jr., 1910, Some causes of oreshoots: Economic Geology, v. 5, p. 913-933.

Peters, S.G., 1990. Lode controls of the Charters Towers goldfield, northeastern Queensland: Australasian Institute Mining Metallurgy Proceedings, no. 2, p. 51-60.

1991, Lode controls of the Hodgkinson goldfield, northeastern Queensland: Australasian Institute Mining Metallurgy Proceedings, no. 2, p. 25-36.

1993a. Formation of oreshoots in mesothermal gold-quartz vein deposits, in Haynes, S.J., ed., Veintype ore deposits: Ore Geology Reviews Special v. 8, p. 277-301.

1993b, Nomenclature, concepts and classification of oreshoots in vein deposits: Ore Geology Reviews, v. 8, p. 3-22.

1996, Definition of the Carlin trend using orientation of fold axes and applications to ore control and zoning in the central Betze orebody, Betze-Post Mine, in Green, Steve, ed., Trip B, Structural Geology of the Carlin Trend, Geology and Ore Deposits of the American Cordillera-A Symposium, Field Guide Compendium: Geological Society of Nevada, Reno, Nevada, p. 59-95.

1998, Evidence for the Crescent Valley-Independence Lineament, north-central, Nevada, in Tosdal, R.M., ed., Contributions to the Gold Metallogeny of Northern Nevada: U.S. Geological Survey Open-File Report 98-338, p. 106-118.

2000, Regional- and district-scale dissolution, deformation and fluid flow in sedimentary rockhosted gold deposits of northern Nevada, in Cluer, J. K., Price, J. G., Struhsacker, E. M., Hardyman, R. F., and Morris, C. L., eds., Geology and Ore Deposits 2000: The Great Basin and Beyond: Geological Society of Nevada Symposium Proceedings, May 15-18, 2000, p. 661-681.

Peters, S.G., Leonardson, R.W., Ferdock, G.C., and Lauha, E.A., 1997, Breccia types in the Betze orebody, Goldstrike Mine, Eureka County, Nevada, in Vikre, Peter, Thompson, T.B., Bettles, K., Christensen, Odin, and Parratt, R., eds., Carlin-type Gold Deposits Field Conference: Society Economic Geology Guidebook Series, v. 28, p. 87-100. 
Peters, S.G., Ferdock, G.C., Woitsekhowskaya, M.B., Leonardson, Robert, and Rahn, Jerry, 1998, Oreshoot zoning in the Carlin-type Betze orebody, Goldstrike Mine, Eureka County, Nevada: U.S. Geological Survey Open-File Report 98-620, 49 p.

Peters S. G., Huang, Jiazhan, Li Zhiping, Jin Chengqui, and Cai, Qiming, 2001a, Geology and Geochemistry of sedimentary rock-hosted Au deposits of the Dian-Qian-Gui area, Guizhou, Yunnan Provinces and Guangxi District, P.R. China, in Peters S.G., ed., Geology, Geochemistry, and Geophysics of sedimentary rock-hosted Au deposits in P.R. China: U.S. Geological Survey Open-File Report (in press).

Peters, S.G., Huang, Jiazhan, and Jin, Chengqui, 2001b, Geology and geochemistry of sedimentary rockhosted Au deposits in the Qin Ling fold belt (Chuan-Shan-Gan) area, Shanxi, Sichuan, and Gansu Provinces, P.R. China, in Peters S.G., ed., Geology, Geochemistry, and Geophysics of sedimentary rock-hosted Au deposits in P.R. China: U.S. Geological Survey Open-File Report (in press).

Peters, S.G., Mark J. Mihalasky' M.J., and Ted G. Theodore, T.G., 2001c, Assessment for sedimentary rockhosted Au-Ag deposits, in Wallace, A.R., Ludington, Steve, Mihalasky, M.J., Peters, S.G., Ponce, D.A., Theodore, T.G, John, D.A., and Berger, B.R, Assessment of Undiscovered Metallic Mineral Resources, Humboldt River Basin, Northern Nevada: U.S. Geological Survey DDS Publication (in press).

Peters, W.C., 1966, The role of the geologist in the life cycle of a mine: Journal Geological Education, v. 14, p. 191-193.

Petersen, U., 1990, Ore distribution, zoning, and exploration of hydrothermal ore deposits: Economic Geology, no. 85, p. 424-435.

Petersen, U., Noble, D.C., Arenas, M.J., and Goodell, D.C., 1977, Geology of the Julcani Mining district, Peru. Economic Geology, no. 72, p. 931-949.

Phillips, J.W., 1972, Hydraulic fracturing and mineralization: Journal Geologic Society London, v. 128, p. 337-359.

1986, Hydraulic fracturing effects in the formation of mineral deposits: Transactions Institute Mining Metallurgy, v. 95, p. B17-B24.

Pillar, C.L., and Drummond, A., 1975, Importance of geological data in planning underground ore extraction: Canadian Institute Mining and Metallurgical Bulletin, v. 68, p. 114-116.

Popoff, C.C., 1966, Computing reserves of mineral deposits: Principles and conventional methods, U.S. Bureau of Mines Information Circular 8283, 113 p.

Poulsen, K.H., and Robert, F., 1989, Shear zones and gold: practical examples from the southern Canadian shield, in Bursnall, J.T., ed., Mineralization and Shear Zones, Geological Association Canada, Short Course Notes, v. 6, p. 239-266.

Radtke, A.S., 1985, Geology of the Carlin gold deposit, Nevada: U.S. Geological Survey Professional Paper $1267,124 \mathrm{p}$.

Ramdohr, P., 1969, The Ore Minerals and Their Intergrowths: Pergamon Press, New York, 1,174 p.

Ramsay, J.G., 1980a, Shear zone geometry: a review: Journal Structural Geology, v. 2, p. 83-99.

Ramsay, J.G., and Huber, M.I., 1983. The Techniques of Modern Structural Geology, Strain Analysis, Academic Press, New York, v. 1, p. 1-307.

1987. The Techniques of Modern Structural Geology, Strain Analysis, Academic Press, New York, 2: 307-700.

Ramsey, J.G., 1980, Shear zone geometry: a review: Journal of Structural Geology, v. 2, no 1/2, p. 83-99.

Raybould, J.G., 1976. The influence of pre-existing planes of weakness in rocks on the localization of veintype ore deposits, Economic Geology, no. 71, p. 636-641.

Reid, R.R., Cadday, S.W., and Rankin, T.W., 1975, Primary refraction control of oreshoots, with examples from the Coeur d'Alene district, Idaho: Economic Geology, v. 70, p. 1,050-1,061.

Resnell, Ricardo, 1990, An anticline trapping model for Carlin-type disseminated gold deposits, in Hausen, D.M., Halbe, D.N., Petersen, E.U., and Tafuri, W.J., eds., Gold '90: Proceedings of the Gold 90 Symposium, Salt Lake City Utah, February 26 to March 1, 1990, p. 21-23. 
Rickard, T.A., 1902. The formation of bonanzas in the upper parts of gold-veins: American Institute Mining Metallurgy Transactions, no. 31, p. 198-220.

Robert, F., and Brown, A.C., 1986a, Achaean gold-bearing quartz veins at the Sigma mine, Abitibi greenstone belt, Quebec: Part I. Geologic relations and formation of the ore district: Economic Geology, no. 81, p. 578-592.

Rose, A.W., and Burt, D.M., 1979, Hydrothermal alteration in, Barnes, H.L., ed., Geochemistry of Hydrothermal Ore Deposits, 2nd Ed., John Wiley, New York, p. 173-235.

Segall, P., and Pollard, D.D., 1980. Mechanics of discontinuous faults: Journal Geophysical Research, no. 85, p. 433-435.

Sibson, R.H., 1977, Fault rocks and fault mechanisms: Journal Geological Society London, v. 133, p. 191213.

1990, Faulting and Fluid flow, in Nesbitt, B.E., ed., Fluids in Tectonically Active Regimes of the Continental Crust: Mineralogical Association Canada. Short Course, no 18, p. 93-109.

Solomon, B.J., McKee, E.H., and Anderson, D.W., 1979, Paleogene rocks near Elko, Nevada, in Armentrout, J.M., Cole, M.R., and Terbest, H. Jr., eds., Cenozoic Paleogeography of the western United States: Society of Economic Paleontologists and Mineralogists, Pacific Section III, p. 75--79.

Snoke, A.W., Tullis, Jan, and Todd, V.R., eds., 1998, Fault-related rocks, a photographic atlas: Princeton University Press, Princeton, 617 p.

Stanton, R. L., 1972, Ore Petrology, McGraw-Hill, New York, 713 p.

Storrar, C.D., ed., 1981, South African Mine Valuation: Chamber of Mines of South Africa, Johannesburg, $470 \mathrm{p}$.

Sverjensky, D.A., 1984, Oil field brines as ore-forming solutions: Economic Geology, v. 79, p. 38-49.

Tchalenko, J.S., 1968, The evolution of kink bands and the development of compression textures in sheared clays. Tectonophysics, no. 6, p. 159-174.

Teagle, D.A.H., Norris, R.J., and Craw, D., 1990. Structural controls on gold-bearing quartz mineralization in a duplex system, Hyde-Macraes Shear Zone, Otago Schist, New Zealand: Economic Geology, no. 85, p. 1,711-1,719.

Tomlinson, K.M. Wilson, C.J.L., Hazeldene, R., and Lohe, E.H., 1988. Structural control on gold mineralization at Wallhala, Victoria: Australian Journal Earth Science, no. 35, p. 421-444.

Treagus, S.H., 1988, Strain refraction in layered systems: Journal Structural Geology, v. 10, p. 517-527. Walsh, J.J., and Watterson, J., 1988. Analysis of the relationship between displacements and dimensions of faults: Journal Structural Geology, no. 10, p. 239-247.

1989, Displacement gradients on fault surfaces: Journal Structural Geology, no. 11,p. 307-316.

Wang, C., Mao, N., and Wu, F.T., 1979, The mechanical property of montmorillonite clay at high pressure and implications on fault behavior: Geophysical Research Letters, v. 6, p. 476478.

Wang, C-Y, and Mao, N., 1979, Shearing of saturated clays in rock joints at high confining pressures: Geophysical Research Letters, v. 6, p. 825-828.

Wells, J.D., and Mullens, T.E., 1973, Gold-bearing As-rich pyrite determined by microprobe analysis, Cortez and Carlin gold mines, Nevada: Economic Geology, v. 68, p. 187-201.

White, S.H., Bretan, P.G., and Ruter, E.H., 1986, Fault-zone reactivation: kinematics and mechanisms: Philosophical Transactions Royal Society London, v. A317, p. 81-97.

Woitsekhowskaya, M., and Peters, S.G., 1998, Geochemical modeling of alteration and gold deposition in the Betze deposit, in Tosdal, R.M., ed., Contributions to the Gold Metallogeny of Northern Nevada: U.S. Geological Survey Open-File Report 98-338, p. 211-222. 